\title{
Neurokinin, Antagonists Potentiate Antidepressant Properties of Serotonin Reuptake Inhibitors, Yet Blunt Their Anxiogenic Actions: A Neurochemical, Electrophysiological, and Behavioral Characterization
}

\author{
Alain Gobert', Mauricette Brocco', Anne Dekeyne', Benjamin Di Cara', Gaëlle Bouchez', \\ Françoise Lejeune', Robert L Gannon ${ }^{2}$ and Mark J Millan*,' \\ 'Psychopharmacology Department, Institut de Recherches Servier, Centre de Recherches de Croissy, Paris, France; ' ${ }^{2}$ Department of Biology, \\ Valdosta State University, Valdosta, GA, USA
}

\begin{abstract}
Though neurokinin, $\left(\mathrm{NK}_{1}\right)$ receptor antagonists are active in experimental models of depression, clinical efficacy has proven disappointing. This encourages interest in association of $\mathrm{NK}_{1}$ receptor blockade with inhibition of serotonin (5-HT) reuptake. The selective NK, antagonist, GR205 I 7I, dose-dependently enhanced citalopram-induced elevations of extracellular levels of 5-HT in frontal cortex, an action expressed stereospecifically vs its less active distomer, GR226206. Further, increases in 5-HT levels in dorsal hippocampus, basolateral amygdala, nucleus accumbens, and striatum were likewise potentiated, and GR205 I7I similarly facilitated the influence of fluoxetine upon levels of 5-HT, as well as dopamine and noradrenaline. In parallel electrophysiological studies, the inhibitory influence of citalopram and fluoxetine upon raphe-localized serotonergic neurones was stereospecifically blunted by GR205I7I. Antidepressant actions of citalopram in a forced-swim test in mice were stereospecifically potentiated by GR205।7I, and it also enhanced attenuation by citalopram of stress-related ultrasonic vocalizations in rats. Further, GR205I7I and citalopram additively abrogated the advance in circadian rhythms provoked by exposure to light in hamsters. By contrast, GR205 I 7 I stereospecifically blocked anxiogenic actions of citalopram in social interaction procedures in rats and gerbils, and stereospecifically abolished facilitation of fearinduced foot tapping by fluoxetine in gerbils. By analogy to GR205 I7I, a further NK I antagonist, RP67580, enhanced the influence of citalopram upon frontocortical levels of 5-HT and potentiated its actions in the forced swim test. In conclusion, NK, receptor blockade differentially modulates functional actions of SSRIs: antidepressant properties are reinforced, whereas anxiogenic effects are attenuated. Combined NK, receptor antagonism/5-HT reuptake inhibition may offer advantages in the management of depressed and anxious states. Neuropsychopharmacology (2009) 34, 1039-1056; doi:I0.1038/npp.2008.176; published online I October 2008
\end{abstract}

Keywords: substance P; neurokinin receptor; dialysis; SSRI; fluoxetine

\section{INTRODUCTION}

In view of the inadequacies of current treatment of depression, considerable efforts are being made to find improved drugs (Millan, 2004, 2006; Morilak and Frazer, 2004). In this regard, much attention has been devoted to $\mathrm{NK}_{1}$ receptors which transduce the actions of substance $\mathrm{P}$ (Rupniak et al, 2001; Holmes et al, 2003). Several preclinical and clinical observations support the utility of $\mathrm{NK}_{1}$ receptor blockade in the control of depressed - and anxious - states. First, long-term treatment with various classes of anti-

*Correspondence: Dr MJ Millan, Neuropharmacology Department, Institut de Recherches Servier, Centre de Recherches de Croissy, I25, Chemin de Ronde, Croissy-sur-Seine 78290, Paris, France,

Tel: + 33 | 557224 25, Fax: + 33 | 557220 82,

E-mail: mark.millan@fr.netgrs.com

Received 9 July 2008; revised 5 August 2008; accepted 19 August 2008 depressant modifies central tissue levels of substance $P$, an effect observed in the absence of an alteration in $\mathrm{NK}_{1}$ receptor expression (Shirayama et al, 1996; Sartori et al, 2004). Second, $\mathrm{NK}_{1}$ receptors are localized in: the dorsal raphe nucleus (DRN), the origin of ascending serotonergic projections (Froger et al, 2001; Santarelli et al, 2001; Commons and Valentino, 2002; $\mathrm{Ma}$ and Bleasdale, 2002; Lacoste et al, 2006); the locus coeruleus, the source of adrenergic input to corticolimbic regions (Santarelli et al, 2001; Ma and Bleasdale, 2002); and the ventrotegmental area (VTA), from which dopaminergic pathways project to the frontal cortex (FCX) and limbic regions (Lessard and Pickel, 2005). Third, $\mathrm{NK}_{1}$ receptors are broadly distributed in limbic structures implicated in the control of mood, such as the FCX, hippocampus, lateral septum, nucleus accumbens, basolateral amygdala (BLA), and hypothalamus (Liu et al, 2002; Saffroy et al, 2003). Fourth, substance P exerts 
aversive effects in rodents, whereas mice genetically deprived of $\mathrm{NK}_{1}$ receptors reveal improved resistance to stress and display an anxiolytic phenotype (Rupniak et al, 2001; Santarelli et al, 2001). Fifth, selective $\mathrm{NK}_{1}$ receptor antagonists exert antidepressant and anxiolytic actions in several, though not all, experimental models (Rupniak et al, 2001; Varty et al, 2002; Dableh et al, 2005; Renoldi and Invernizzi, 2006), and they attenuate the behavioral response to stress (Ebner et al, 2004).

The above observations prompted clinical evaluation of several selective $\mathrm{NK}_{1}$ receptor antagonists, including MK869 (aprepitant) and L759274, which revealed beneficial effects in major depression with improved tolerance (less sexual dysfunction) as compared to SSRIs (Kramer et al, 1998, 2004; Gerald et al, 2006). Nonetheless, therapeutic trials of $\mathrm{NK}_{1}$ antagonists have not overall yielded convincing evidence of robust and reproducible antidepressant actions, tempering enthusiasm for their further development. This has triggered interest in the concept of combining $\mathrm{NK}_{1}$ antagonist properties with suppression of 5-HT reuptake, either as drug associations or in a single chemical structure (Ryckmans et al, 2002; Guiard et al, 2004; Millan, 2006). Such agents would be expected to exert complementary antidepressant properties, potentially with greater efficacy and rapidity of action than SSRIs and selective $\mathrm{NK}_{1}$ blockers, respectively. Support for this notion has been generated by both neurochemical and electrophysiological studies in rodents. Thus, the influence of SSRIs upon extracellular levels of 5-HT in FCX was reinforced in mice genetically lacking $\mathrm{NK}_{1}$ receptors, possibly due to desensitization of feedback actions at inhibitory 5- $\mathrm{HT}_{1 \mathrm{~A}}$ autoreceptors in the DRN (Froger et al, 2001; Santarelli et al, 2001; Guiard et al, 2005; Gobbi et al, 2007). By analogy, Guiard et al (2004) demonstrated that the effect of paroxetine on frontocortical 5-HT levels in mice were potentiated by the $\mathrm{NK}_{1}$ antagonists, GR205171 and L733060.

These elegant studies underpin the notion that $\mathrm{NK}_{1}$ receptor blockade may enhance the influence of SSRIs upon serotonergic transmission, but several important issues and questions remain to be addressed. First, neurochemical studies of the influence of $\mathrm{NK}_{1}$ antagonists on the actions of SSRIs have to date been restricted to mice, and it would be desirable to reproduce such findings in other species. Second, the influence of $\mathrm{NK}_{1}$ receptor blockade upon SSRIelicited increases in 5-HT levels has been evaluated in the FCX, but it would be interesting to extend such work to other corticolimbic structures implicated in depressed states, like the hippocampus, BLA, nucleus accumbens, and striatum. Third, certain 'SSRIs' also enhance extracellular levels of noradrenaline (NA) and dopamine (DA) in FCX (Millan et al, 2000), but it has not been determined whether $\mathrm{NK}_{1}$ receptor antagonists likewise modify the influence of SSRIs upon dopaminergic and adrenergic transmission. Fourth, subactive doses of SSRIs exert antidepressant actions in the mouse forced swim (FS) test in the presence of GR205171 (Chenu et al, 2006). Remarkably, however, no other data on how $\mathrm{NK}_{1}$ antagonists may modify the behavioral actions of SSRIs are available. In this light, it would be of particular interest to examine whether the acute anxiogenic actions of SSRIs (Dekeyne et al, 2000) are modified by blockade of $\mathrm{NK}_{1}$ receptors.
The present studies addressed these questions employing combined neurochemical, electrophysiological, and behavioral approaches, together with the highly selective $\mathrm{NK}_{1}$ receptor antagonist, GR205171. In contrast to most agents, GR205171 possesses high affinity at $\mathrm{NK}_{1}$ receptors across a broad range of species, though its affinity is higher for $\mathrm{NK}_{1}$ receptors in gerbils and guinea pigs (which closely resemble those in humans) than rats and mice (Rupniak et al, 2000; Griffante et al, 2006; Engberg et al, 2007). GR205171 was also chosen in view of its well-characterized actions in vivo (Gardner et al, 1996; Millan et al, 2001b; Lejeune et al, 2002; Guiard et al, 2004; Chenu et al, 2006), and as clinical studies have shown that it relieves social phobia (Furmark et al, 2005; Michelgard et al, 2007). To underpin the stereospecificity of the actions of GR205171, its effects were compared to those of its less active distomer, GR226206 (op. cit.).

\section{MATERIALS AND METHODS}

\section{Animals}

Unless specified below, these studies employed male Wistar rats (225-250 g body weight upon arrival) and male CD mice (22-26g upon arrival) supplied by Charles River (L'Arbresle and Saint Aubin les Elbeuf, France, respectively). Male Mongolian gerbils (50-70 g upon arrival) were acquired from CERJ (Le Genest, St-Isle, France). Male Syrian hamsters (70-80 g upon arrival) were obtained from Charles River Laboratories (Kingston, NY, USA). Rats, mice, and gerbils were housed in standard Macrolon, sawdustlined cages and hamsters were housed in polycarbonate cages lined with sterilized pine chips and unrestricted access to food and water. Except for hamsters (see below), there was a light/dark cycle with lights on from $07: 30$ to 19:30 hours. All animal use procedures conformed to international European ethical standards (86/609-EEC) and the French National Committee (décret 87/848) for the care of laboratory animals. Hamster use was approved by the Institutional Animal Care and Use Committee of Valdosta State University and complied with regulations outlined in the US Animal Welfare Act.

\section{Cerebral Microdialysis and Chromatographic Procedures}

The protocol used for quantification of levels of 5-HT, DA, and NA in dialysate samples was detailed elsewhere (Millan et al, 2001b). Briefly, a guide-cannula was implanted under pentobarbital anesthesia $(60 \mathrm{mg} / \mathrm{kg}$, i.p.) into the FCX, nucleus accumbens, striatum, or dorsal hippocampus of rats as previously described (Millan et al, 2001b). For the BLA, coordinates were AP, 2.8; ML, \pm 4.9 ; and DV, 6.4 from dura. Experiments were performed 5 days later after placement of the guide cannula following placement of a cuprophane CMA/11 probe: $0.24 \mathrm{~mm}$ in diameter, $4 \mathrm{~mm}$ in length for FCX and striatum, and $2 \mathrm{~mm}$ for the dorsal hippocampus, BLA and nucleus accumbens. Samples were taken every 20 min over $1 \mathrm{~h}$, then GR205171 or vehicle was injected i.p. followed, $20 \mathrm{~min}$ later, by s.c. administration of citalopram, fluoxetine, 8-OH-DPAT or S15535. In further experiments, injection of citalopram was preceded by treatment with GR226206 or RP67580. Sampling was 
pursued for a further $3 \mathrm{~h}$. Monoamine levels were quantified as described previously (above citations) by HPLC and electrochemical detection.

\section{Electrophysiological Procedure}

As detailed previously (Lejeune et al, 2002), rats were anaesthetized with chloral hydrate $(400 \mathrm{mg} / \mathrm{kg}$, i.p.) and, after cannulation of the femoral vein, placed in a stereotaxic apparatus. A tungsten microelectrode was slowly lowered into the DRN (from bregma and the sinus surface, AP, 7.2; $\mathrm{ML}, \pm 0.0$; and DV, 5.5/6.5). After amplification (CP511; Grass Technology, USA) and A/D conversion (micro1401mkII; CED, Cambridge, UK) of electrical activity, data were recorded using Spike2 software (CED). Serotonergic neurones were identified by their waveform and spontaneous firing patterns $(\approx 1.2 \mathrm{~Hz})$. One cell was recorded per animal. The spontaneous firing rate was recorded for $5 \mathrm{~min}$ before i.v. administration of vehicle, GR205171, or GR226206. After $3 \mathrm{~min}$, the influence of citalopram, fluoxetine, 8-OH-DPAT, S15535, (-)-pindolol, or buspirone, injected i.v. in volumes of $0.5 \mathrm{ml} / \mathrm{kg}$, was evaluated upon administration in cumulative doses at intervals of 2-3 min. Drug effects were characterized over $60 \mathrm{~s}$ periods at the time of peak action.

\section{Forced Swim Test in Mice}

As previously described (Brocco et al, 2006), mice were placed in individual glass cylinders $(24 \mathrm{~cm} \mathrm{~h} \times 12 \mathrm{~cm}$ diameter) containing $6 \mathrm{~cm}$ of water at $25^{\circ} \mathrm{C}$ for $6 \mathrm{~min}$. Immobility (s) was measured during the last $4 \mathrm{~min}$ of the test. In dose-range studies of citalopram (s.c.) and GR205171 (i.p.), drug or vehicle was administered $30 \mathrm{~min}$ before testing. In antagonist studies, GR205171, GR226206, RP67580, or vehicle was administered (i.p.) $30 \mathrm{~min}$ before treatment with citalopram $(2.5 \mathrm{mg} / \mathrm{kg}$, s.c. $)$ or vehicle, and testing undertaken 30 min later.

\section{Influence Upon Locomotor Activity in Mice}

As described (Brocco et al, 2002), locomotor activity in mice was evaluated using white Plexiglass cages $(27 \times 27 \times 27 \mathrm{~cm})$ equipped with two rows of four photocells $2 \mathrm{~cm}$ above the floor and $6 \mathrm{~cm}$ apart connected through an interface to a microcomputer (Hesperid, Loiron, France). GR205171 or vehicle (i.p.), then citalopram or vehicle (s.c.), was administered 60 and $30 \mathrm{~min}$ before placing mice in individual activity chambers for $10 \mathrm{~min}$. Each interruption of an infrared beam was counted as a movement.

\section{Ultrasonic Vocalization Test in Rats}

As previously (Millan et al, 2001a), rats were initially placed in a chamber equipped with a grid floor and were exposed to six randomly distributed, electric shocks $(800 \mu \mathrm{A}, 8 \mathrm{~s})$ over a $7 \mathrm{~min}$ period. After $24 \mathrm{~h}$, they were placed in the chamber for 2 min and received a single shock. They were returned to the chamber 30 min later and the total duration of ultrasonic vocalizations (USVs), defined as vocalizations with frequencies higher than $20 \mathrm{kHz}$, were recorded as previously (Millan et al, 1997a) over 10-min by use of a microphone linked to an ultrasound recording system
(Ultravox; Noldus, Wageningen, The Netherlands). Rats emitting USVs for less than $90 \mathrm{~s}$ were not examined further. After $24 \mathrm{~h}$, the procedure was replicated following drug administration. GR205171, GR226206, citalopram or vehicle was administered immediately after the 2 min session and, in potentiation studies, animals received GR205171, GR226206 or vehicle, followed by citalopram or vehicle, immediately after the 2 min session.

\section{Fear-Induced Foot Tapping in Gerbils}

As previously (Brocco et al, 2008), the procedure involved two sessions: (1) acquisition of fear conditioning followed, $4 \mathrm{~h}$ later, by (2) a test session. The apparatus was a chamber with a floor comprised of four metal plates $(10 \times 4 \mathrm{~cm})$ connected to a shocker (Apelex, Massy, France). In the acquisition session, naive gerbils were placed for $2 \mathrm{~min}$ habituation in the chamber, then a shock was $(1.75 \mathrm{~mA}$, $0.5 \mathrm{~s}$ ) delivered manually each time the animal crossed from one plate to another. Each animal received 10 shocks, separated by at least $10 \mathrm{~s}$ intervals without shock. For testing, the animal was placed again in the four-plate chamber for $3 \mathrm{~min}$ and the duration (s) of foot-tapping bouts recorded. No shock was delivered during the test session. GR205171, GR226206, or vehicle was administered i.p. together with either vehicle or fluoxetine $(40.0 \mathrm{mg} / \mathrm{kg}$, i.p.), $30 \mathrm{~min}$ before the test session.

\section{Social Interaction Tests in Rats and Gerbils}

As previously (Millan et al, 2001a; Brocco et al, 2008), male Sprague-Dawley rats of 240-260 g (Charles River, SaintAubin-les-Elbeuf, France) or gerbils were maintained under a 12/12 h low light ( 3 lux)/dark cycle for 5 days before testing, and individually housed 5 days (rats) or $3 \mathrm{~h}$ (gerbils) before testing. On the test day, they were placed in weight-matched pairs ( $\pm 5 \mathrm{~g}$ for rats and $\pm 3 \mathrm{~g}$ for gerbils) in opposite corners of a highly illuminated (300 lux) open-topped arena for a 10 (rats) or $5 \mathrm{~min}$ (gerbils) observation session. Data were the duration of active SI: ie, the time spent in grooming, following, sniffing, biting, jumping, or crawling over or under the other animal. If animals remained adjacent to each other without any movement for more than $10 \mathrm{~s}$, scoring was discontinued until active SI resumed. Both animals of the same pair receive the same drug treatment. GR205171, citalopram, or vehicle was administered $30 \mathrm{~min}$ before testing. In interaction studies, GR205171, GR226206, or vehicle was administered $45 \mathrm{~min}$ before testing, and citalopram or vehicle $30 \mathrm{~min}$ before testing.

\section{Light-Induced Phase-Advances in Circadian Wheel Running Rhythms in Hamsters}

As previously (Gannon and Millan, 2007), Syrian hamsters were maintained in a $14: 10 \mathrm{~h}$ light: dark schedule for several weeks before being transferred to conditions of constant darkness (DD) where they had access to small running wheels of $19 \mathrm{~cm}$ in diameter. Wheel running was recorded in $10 \mathrm{~min}$ bins using Actimetrics ClockLab hardware (Evanstown, IL, USA). Food and water was provided ad libitum at all times. Onset of wheel running in DD is defined as circadian time (CT 12). Data were 
recorded for approximately 10 days in $\mathrm{DD}$ and then hamsters were removed from their home cages under dim red light $(<1$ lux $)$ at circadian time 18.25 , weighed, and injected with either drug or vehicle and returned to their home cage. After $45 \mathrm{~min}$ at CT, 19 hamsters were again removed from their home cage and exposed to a $10-\mathrm{min}$ pulse of white light (20 lux) and then returned to their home cage for another 10 days. Hamsters were returned to the $14: 10 \mathrm{~h}$ lighting schedule at the conclusion of the experiment. Light pulses delivered at CT 19 to hamsters in DD phase advance the time of onset of wheel running. The magnitude of the phase advance was determined by fitting a line through the activity onset for several days before the light pulse and again for several days after the light pulse once the rhythm has stabilized, normally days 5-10 after light. The difference in time between the two fitted lines on the day of the experiment indicates the magnitude of the light-induced phase advance.

\section{Drugs and Sources}

Drug doses are expressed in terms of the base. Drugs were dissolved in distilled water and administered s.c., i.p., or i.v. (electrophysiology). For i.p. administration, drugs were administered as suspensions in water with a few drops of Tween 80. GR205171 (2-methoxy-5-(5-trifluoromethyltetrazol-1-yl)-benzyl-([2S,3S]-2-phenylpiperidinyl)-amine) diHCl; GR226206 (2-methoxy-5-(5-trifluoromethyltetrazol-1-yl)benzyl-([2R,3R]-2-phenylpiperidinyl)-amine) diHCl; citalo- pram $\mathrm{HBr}$, RP67580 ((3aR,7aR)-imino-1(methoxy-2-phenyl)-2-diphenyl-7,7-perhydro isoindolone-4), and $\$ 15535$ (1-(1,4-benzodioxan-5-yl)-4-(indan-2-yl) piperazine mesylate) were synthetized by Servier chemists. 8-OH-DPAT (8dihydroxy-2(di- $n$-propylamino)tetralin) $\mathrm{HBr},(-)$-pindolol, WAY-100,635 (N-(2-(4-(2-methoxyphenyl)piperazin-1yl)ethyl)- $N$-(2-pyridyl)cyclohexane carboxamide) maleate and buspirone were purchased from Sigma-RBI (Natick, USA). Fluoxetine $\mathrm{HCl}$ was purchased from Interchim (Montluçon, France).

\section{RESULTS}

\section{Enhancement by GR205171 of the Influence of Citalopram and Fluoxetine Upon Dialysis Levels of 5-HT in Frontal Cortex of Freely Moving Rats}

At a dose of $0.63 \mathrm{mg} / \mathrm{kg}$, s.c., citalopram markedly increased levels of 5-HT in the FCX of freely moving rats (Figure 1; Table 1). In contrast, levels of DA and NA were not modified. In an opposite fashion, the selective $\mathrm{NK}_{1}$ antagonist, GR205171 (10.0-40.0 mg/kg, s.c.), had no effect on frontocortical levels of 5-HT, whereas it elevated levels of DA and NA. This effect of GR205171 was expressed stereospecifically in that its less active distomer, GR226206 (40.0 mg/kg, s.c.), did not significantly influence levels of DA, NA, or 5-HT ( $p>0.05$, not shown). GR205171 (10.0-40.0 mg/kg, i.p.) dose-dependently potentiated the increase in extracellular levels of 5-HT induced by citalopram (0.63). This effect was exerted

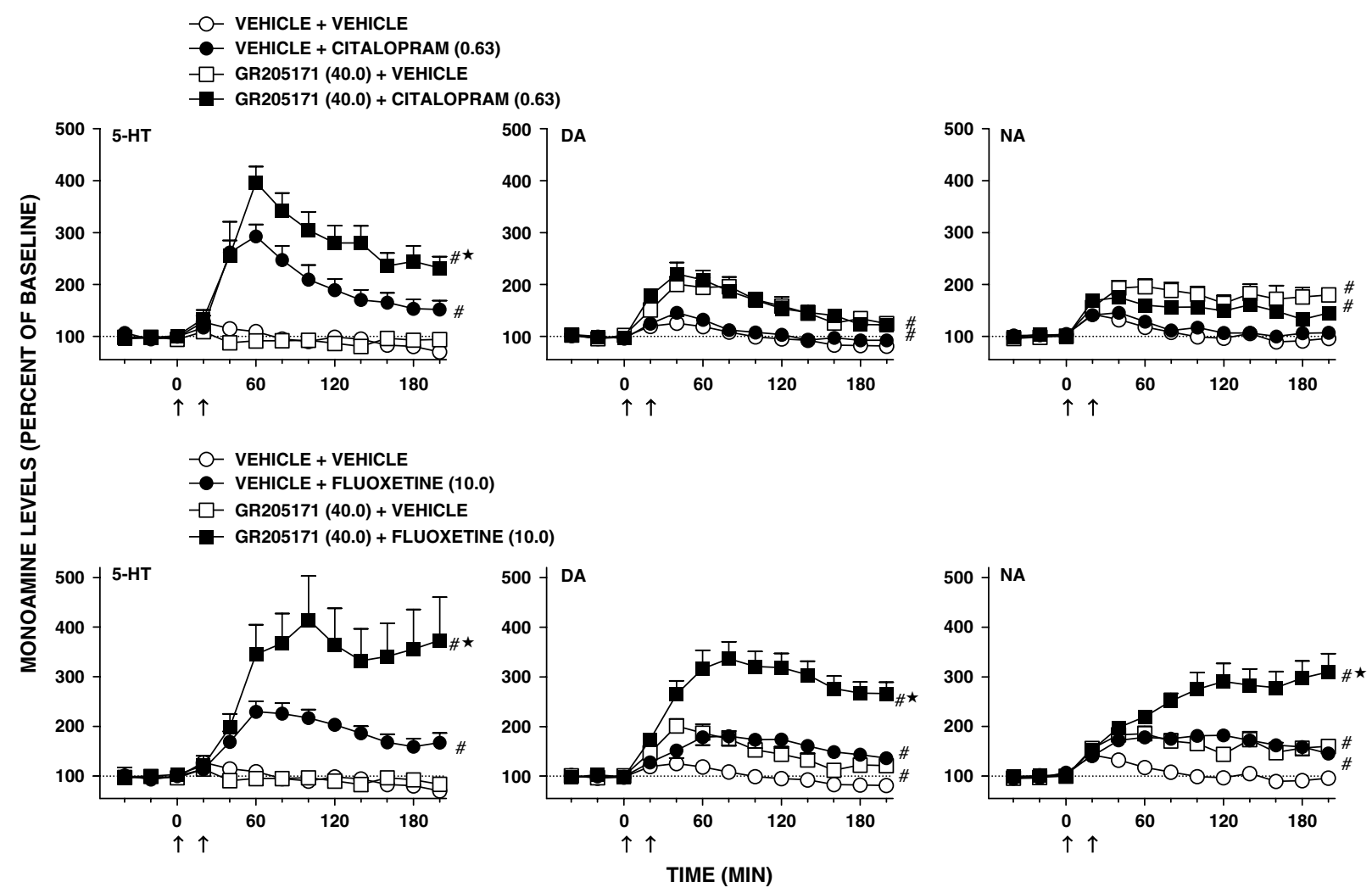

Figure I Enhancement by the neurokinin (NK), receptor antagonist, GR205 I7I, of the influence of citalopram upon dialysis levels of serotonin in frontal cortex of freely-moving rats. Serotonin (5-HT), dopamine (DA), and noradrenaline (NA) levels are expressed relative to basal values defined as $100 \%$. These were $0.96 \pm 0.06,1.12 \pm 0.07$, and $1.84 \pm 0.08$ pg per $20 \mu \mathrm{l}$ for $5-\mathrm{HT}$, DA, and NA respectively. Data are means $\pm \mathrm{SEMs}$; $N=5-9$ per value. Arrows denote the injection of drugs. For ANOVA with dose as between factor, see legend to Table I. 
Table I Enhancement by NK, Receptor Antagonists of the Influence of Citalopram and Fluoxetine Upon Dialysis Levels of Serotonin in Frontal Cortex

\begin{tabular}{|c|c|c|c|}
\hline Drug & Serotonin & Dopamine & Noradrenaline \\
\hline $\mathrm{VEH}+\mathrm{VEH}$ & $93.1 \pm 2.5$ & $98.7 \pm 2.7$ & $104.1 \pm 3.0$ \\
\hline$G R(I 0.0)+V E H$ & $102.2 \pm 4.1$ & $112.9 \pm 3.6$ & $138.6 \pm 3.2^{\#}$ \\
\hline GR $(40.0)+V E H$ & $90.7 \pm 2.5$ & $161.3 \pm 5.6^{\#}$ & $181.6 \pm 5.3^{\#}$ \\
\hline VEH+CITAL (0.63) & $204.8 \pm 10.7^{\#}$ & $108.6 \pm 3.3$ & $1 \mid 4.4 \pm 3.6$ \\
\hline GR (40.0)+CITAL (0.63) & $285.8 \pm 11.0^{\#, *}$ & $163.7 \pm 5.9^{\# *_{*}}$ & $154.0 \pm 3.2^{\#, *}$ \\
\hline VEH+FLUOX (I0.0) & $191.9 \pm 6.3^{\#}$ & $161.0 \pm 5.2^{\#}$ & $170.0 \pm 3.3^{\#}$ \\
\hline GR $(I 0.0)+F L U O X(I 0.0)$ & $218.2 \pm 13.5^{\#}$ & $186.8 \pm 4.4^{\#}$ & $195.1 \pm 4.5^{\#}$ \\
\hline GR (20.0)+FLUOX (I0.0) & $296.5 \pm 9.0^{\# \text {,* }}$ & $192.5 \pm \mid 2.1^{\#}$ & $198.2 \pm 5.3^{\#}$ \\
\hline GR (40.0)+FLUOX (10.0) & $343.8 \pm 22.5^{\#, *}$ & $297.0 \pm 9.5^{\#, *}$ & $267.2 \pm 9.9^{\#, *}$ \\
\hline
\end{tabular}

VEH, vehicle; GR, GR205I7I; CITAL, citalopram; FLUOX, fluoxetine; RP, RP67580.

Data (means \pm SEMs) represent 'area under the curve' analysis expressed relative to basal values (I00\%). For basal values, see legend of Figure I. $N=5-10$ per value.

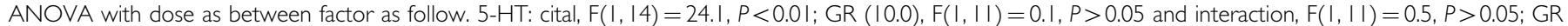
(20.0), $F(I, I 2)=0.5, P>0.05$ and interaction, $F(I, I 2)=0.9, P>0.05 ; G R(40.0), F(I, I 5)=0.2, P>0.05$ and interaction, $F(I, I 5)=5.5, P<0.05 . D A: c i t a l$, $F(I, I 5)=2.2, P>0.05 ; G R(I 0.0), F(I, I 2)=4.6, P>0.05$ and interaction, $F(I, I 2)=5.5, P<0.05 ; G R(20.0), F(I, I 3)=45.4, P<0.05$ and interaction, $F(I, I 2)=I 0.6$, $P<0.05$; GR (40.0), $F(I, I 6)=31.4, P<0.01$ and interaction, $F(I, I 4)=17.3, P<0.01$. NA: cital, $F(I, I 5)=0.3, P>0.05 ; G R(I 0.0), F(I, I 2)=39.7, P<0.05$ and interaction, $F(I, I 2)=1.7, P>0.05 ; G R(20.0), F(I, I 3)=22.8, P<0.05$ and interaction, $F(I, I 2)=4.4, P>0.05 ; G R(40.0), F(I, I 6)=29.3, P<0.0 I$ and interaction, $F(I, \mid 4)=15.2, P<0.01$. 5-HT: fluox, $F(I, I 6)=43.8, P<0.0 I ; G R(I 0.0), F(I, I I)=0 . I, P>0.05$ and interaction, $F(I, I 3)=0.7, P>0.05 ; G R(20.0), F(I, I 2)=0.5$, $P>0.05$ and interaction, $F(I, I 5)=23.9, P<0.05 ; G R(40.0), F(I, I 5)=0.2, P>0.05$ and interaction, $F(I, I 4)=\mid 0.2, P<0.0 I$. DA: fluox, $F(I, I 7)=\mid 6.0, P<0.0 I ; G R$ $(I 0.0), F(I, I 5)=1.7, P>0.05$ and interaction, $F(I, I 2)=5.5, P<0.05 ; G R(20.0), F(I, I 3)=45.4, P<0.05$ and interaction, $F(I, I 5)=0.9, P>0.05 ; G R(40.0)$,

$F(I, I 6)=31.4, P<0.01$ and interaction, $F(I, I 6)=26.7, P<0.0 I$. NA: fluox, $F(I, I 7)=58.8, P<0.0 I ; G R(I 0.0), F(I, I 2)=39.7, P<0.05$ and interaction,

$F(I, I 5)=3.8, P>0.05 ; G R(20.0), F(I, I 3)=22.8, P<0.05$ and interaction, $F(I, I 5)=3.5, P>0.05 ; G R(40.0), F(I, I 6)=29.3, P<0.0 I$ and interaction, $F(I, I 6)=I 7.7$, $P<0.01$. 5-HT: RP, $F(I, I I)=0.2, P>0.05$ and interaction, $F(I, I I)=6.9, P<0.05$. DA: RP, $F(I, I 2)=|8.0, P<0.0|$ and interaction, $F(I, I I)=4.4, P>0.05$. NA: RP, $F(I, I 2)=37.7, P<0.01$ and interaction, $F(I, I I)=0.5, P>0.05$.

${ }^{\#}$ Significance $(P<0.05)$ of drug-treated vs vehicle-treated groups; *significance $(P<0.05)$ of drug/CITAL-treated groups vs VEH/CITAL-treated group or GR/FLUOXtreated groups vs VEH/FLUOX-treated group.

stereospecifically in that GR226206 (40.0) did not significantly modify the citalopram-induced increase in 5-HT levels. Area under the curve analyses (\%, expressed relative to basal values, defined as $100 \%$ ) is as follows: vehicle/citalopram $(0.63)=204.8 \pm 10.7$ vs GR226206 (40)/citalopram $(0.63)=$ $207.3 \pm 11.3, P>0.05$. The combination of GR205171 with citalopram did not differentially influence levels of DA and NA as compared to GR205171 alone. There was no significant influence of GR226206 in combination with citalopram upon levels of DA and NA ( $P>0.05$, not shown). GR205171 (10.0$40.0 \mathrm{mg} / \mathrm{kg}$, i.p.) also dose-dependently potentiated the increase in extracellular levels of 5-HT induced by fluoxetine in FCX. This effect was expressed stereospecifically in that GR226206 (40.0) was inactive. Area under the curve analyses is as follows: vehicle/fluoxetine (10.0) vs GR226 206/fluoxetine (10.0), $5-\mathrm{HT}=191.9 \pm 6.3$ vs $215.5 \pm 7.7, P>0.05$. In addition, at a dose of $10.0 \mathrm{mg} / \mathrm{kg}$, s.c., fluoxetine increased levels of DA and NA. In the presence of increasing doses of GR205171 $(10.0-40.0 \mathrm{mg} / \mathrm{kg}$, i.p.), fluoxetine enhanced levels of DA and NA. GR226206 did not modify the influence of fluoxetine upon DA and NA levels. Area under the curve analysis: vehicle/fluoxetine (10.0) vs GR226206 (40.0)/fluoxetine (10.0), $\mathrm{DA}=161.0 \pm 5.2$ vs $172.9 \pm 4.7, P>0.05$ and $\mathrm{NA}=170.0 \pm 3.3$ vs $184.1 \pm 3.6, P>0.05$.

\section{Enhancement by GR205171 of the Influence of Citalopram Upon Dialysis Levels of 5-HT in Diverse Cerebral Structures of Freely Moving Rats}

In the dorsal hippocampus, BLA, nucleus accumbens, and striatum, at a dose of $0.63 \mathrm{mg} / \mathrm{kg}$, s.c., citalopram increased levels of 5-HT (Figure 2; Table 2). It also slightly elevated the levels of DA and NA in the BLA. By contrast, it did not affect NA (dorsal hippocampus) or DA (nucleus accumbens and striatum). GR205171 (40.0 mg/kg, s.c.), did not affect 5HT levels in any structure. It did not modify DA levels in nucleus accumbens, and slightly decreased DA levels in striatum. However, it enhanced levels of DA in the BLA and those of NA in BLA and dorsal hippocampus. In the presence of GR205171, the influence of citalopram upon 5HT was potentiated, but changes in DA and NA were not modified.

\section{Attenuation by GR205171 of the Inhibitory Influence of Citalopram and Fluoxetine Upon the Firing Rate of Serotonergic Neurones}

Citalopram suppressed the electrical activity of DRNlocalized serotonergic neurones (Figure 3). Administered 

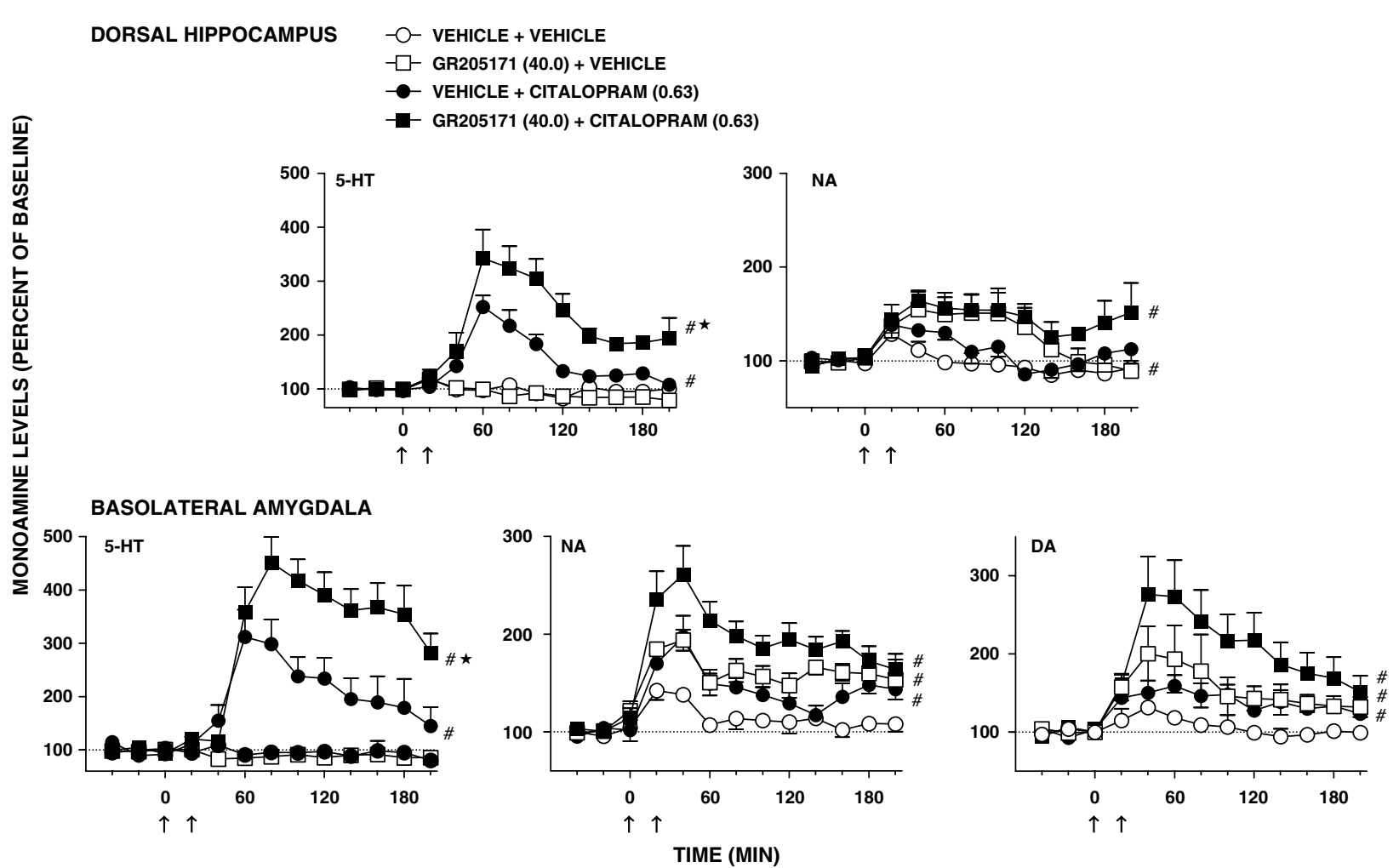

Figure 2 Enhancement by GR205 I7I of the influence of citalopram upon dialysis levels of serotonin in dorsal hippocampus and basolateral amygdala of freely moving rats. Serotonin (5-HT), dopamine (DA) and noradrenaline (NA) levels are expressed relative to basal values defined as $100 \%$. These were $1.42 \pm 0.10$ and $0.79 \pm 0.14 \mathrm{pg}$ per $20 \mu \mathrm{l}$ for NA and $5-\mathrm{HT}$ in the dorsal hippocampus, respectively, and $0.9 \mathrm{I} \pm 0.05,0.47 \pm 0.05$, and $0.62 \pm 0.10 \mathrm{pg}$ per $20 \mu \mathrm{l}$ for NA, DA, and 5-HT in the BLA, respectively. Data are means \pm SEM; $N=5-8$ per value. Arrows denote the injection of drugs. ANOVA as follows. Dorsal hippocampus, 5-HT: citalopram, $F(I, I I)=33.3, P<0.01$; GR205 I II, $F(I, I 3)=2 . I, P>0.05$ and interaction, $F(I, 8)=7.5, P<0.05$ and NA: citalopram, $F(I, I I)=4.5, P>0.05$; GR205 I 7I, $F(I, I 3)=7.6, P<0.05$ and interaction, $F(I, 8)=5 . I, P>0.05$. BLA, 5-HT: citalopram, $F(I, 9)=7 . I, P<0.05 ;$ GR205 I 7I, $F(I, 9)=0 . I, P>0.05$ and interaction, $F(I, I I)=5.6, P<0.05$; DA: citalopram, $F(I, 9)=10.5, P<0.05$; GR205I $7 \mathrm{I}, F(I, 8)=7.5, P<0.05$ and interaction, $F(I, \mid I)=4 . I, P>0.05$ and $N A$ : citalopram, $F(I, 9)=7.2, P<0.05$; GR205 I II, $F(I, 9)=16.2, P<0.01$ and interaction, $F(I, I I)=3.5, P>0.05$. Significance $(P<0.05)$ of drug-treated groups vs vehicle-treated groups is indicated by ${ }^{\#}$, and significance $(P<0.05)$ of GR205 I7l/citalopram-treated groups vs vehicle/ citalopram-treated groups is indicated by asterisks.

Table 2 Enhancement by GR205 I7I of the Influence of Citalopram Upon Dialysis Levels of Serotonin in Striatum and Nucleus Accumbens

Striatum

Nucleus Accumbens

\begin{tabular}{|c|c|c|c|c|}
\hline \multirow[b]{2}{*}{ Drug } & & \\
\hline & Serotonin & Dopamine & Serotonin & Dopamine \\
\hline VEH+VEH & $96.0 \pm 2.4$ & $96.5 \pm 2.0$ & $103.3 \pm 2.0$ & $98.9 \pm 1.9$ \\
\hline GR (40.0)+VEH & $97.7 \pm 3.1$ & $83.2 \pm 1.4^{\#}$ & $98.2 \pm 3.8$ & $91.8 \pm 3.1$ \\
\hline VEH+CITAL (0.63) & $200.6 \pm 7.9^{\#}$ & $99.2 \pm 1.8$ & $202.8 \pm 9.9^{\#}$ & $103.5 \pm 3.5$ \\
\hline GR (40.0)+CITAL (0.63) & $302.7 \pm 10.4^{\#, *}$ & $89.6 \pm 2.0$ & $328.5 \pm 13.4^{\#, *}$ & $85.8 \pm 1.8$ \\
\hline
\end{tabular}

VEH, vehicle; GR, GR205I7I; CITAL, citalopram.

Data are means \pm SEMs and represent 'area under the curve' analysis expressed relative to basal values (I00\%). Basal values were $12.9 \pm 1.6$ and $0.46 \pm 0.05$ pg per $20 \mu \mathrm{l}$ for DA and 5-HT in the striatum, respectively, and $3.8 \pm 0.4$ and $0.39 \pm 0.03 \mathrm{pg}$ per $20 \mu \mathrm{l}$ for DA and $5-\mathrm{HT}$ in the nucleus accumbens, respectively. $\mathrm{N}=6-9$ per value. ANOVA as follows. Striatum, serotonin: citalopram, $F(I, I 2)=24.0, P<0.01$; GR205I II, $F(I, I 4)=0 . I, P>0.05$ and interaction, $F(I, I 2)=\mid 2.5, P<0.0 I$.

Dopamine: citalopram, $F(I, I 2)=0.2, P>0.05$; GR205 I II, $F(I, I 4)=4.7, P<0.05$ and interaction, $F(I, I 2)=2.0, P>0.05$. Nucleus accumbens, serotonin: citalopram, $F(I, I 3)=30.7, P<0.01$; GR205 I7I, $F(I, I 5)=1.3, P>0.05$ and interaction, $F(I, I 0)=10.8, P<0.01$. Dopamine: citalopram, $F(I, \mid 3)=0.2, P>0.05 ; G R 205|7|$, $F(I, I 5)=0.6, P>0.05$ and interaction, $F(I, I 0)=2.4, P>0.05$.

\#Significance $(P<0.05)$ of drug-treated vs vehicle-treated groups; *significance $(P<0.05)$ of GR205 I7l/citalopram-treated vs vehicle/citalopram-treated groups.

alone, GR205171 failed to modify firing rate. However, it dose-dependently (1.0-4.0 mg/kg, i.v.) and significantly displaced the dose-response curve for inhibition of serotonergic neurones by citalopram to the right. The effects of citalopram alone and of citalopram in the presence of GR205171 were both blocked by the selective $5-\mathrm{HT}_{1 \mathrm{~A}}$ receptor antagonist, WAY100635 $(0.1 \mathrm{mg} / \mathrm{kg}$, i.v. $)$ (Newman-Tancredi et al, 1998). In distinction to GR205171, 


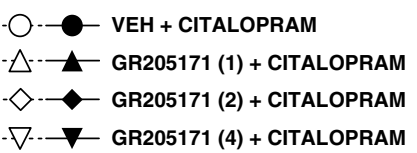

O- VEH + FLUOXETINE

$-\triangle-\triangle-$ GR205171 (1) + FLUOXETINE

$-\diamond-\prec$ GR205171 (2) + FLUOXETINE

$--\nabla-\nabla-$ GR205171 (4) + FLUOXETINE
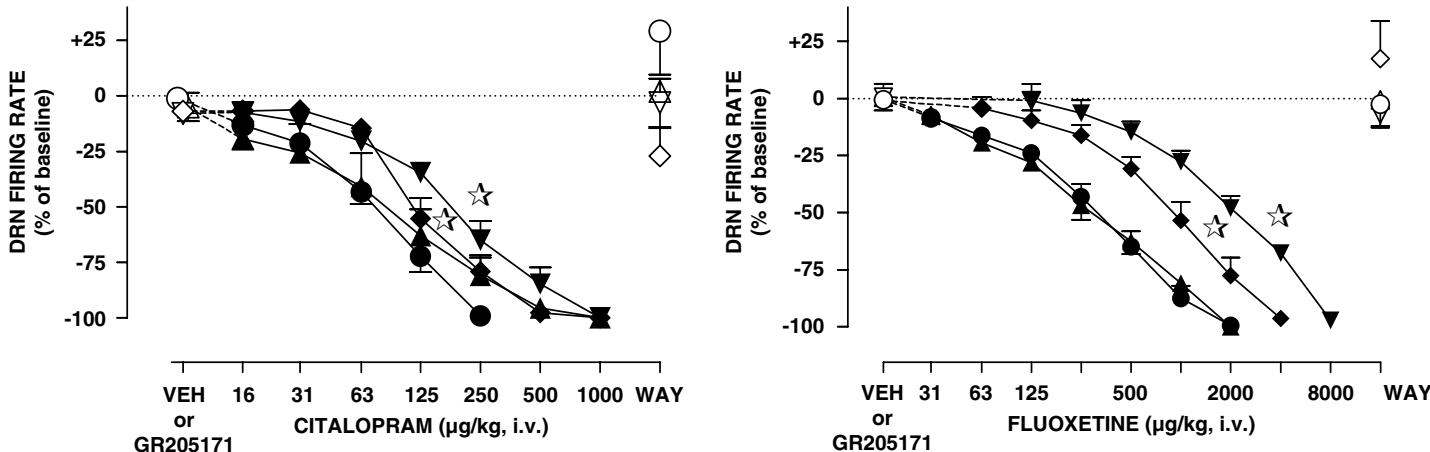

Figure 3 Attenuation by GR205 I7I of the inhibitory influence of citalopram and fluoxetine upon the firing rate of serotonergic neurones in anesthetized rats. $V E H=$ vehicle; WAY $=$ WAY 100635 . The influence of drugs is expressed as the percentage change from baseline defined as $0 \%$. Baseline firing rate, $1.2 \pm 0.2 \mathrm{~Hz}$. Data are means \pm SEMs; $N=5-9$ per value. Two-way ANOVA as follows. VEH + citalopram vs GR205I7I $(I)+$ citalopram, F $(8, I I 2)=1.8$, $P>0.05$; VEH + citalopram vs GR205I7I (2) + citalopram, $F(8,96)=10.5, P<0.01 ; V E H+$ citalopram vs GR205I7I (4) + citalopram, $F(8, I I 2)=8.7$, $P<0.0$ I; VEH + fluoxetine vs GR205 I 7 I (I) + fluoxetine, $F(8,72)=0.3, P>0.05 ; \mathrm{VEH}+$ fluoxetine vs GR205 I 7 I $(2)+$ fluoxetine, $F(I 0, I 00)=4.5, P<0.0$ I; $\mathrm{VEH}+$ fluoxetine vs GR205I7I (4) + fluoxetine, $F(I 0, I 00)=10.9, P<0.01$. Asterisks indicate significance $(P<0.05)$ of GR205I7I-treated groups vs vehicletreated group.

its less active distomer, GR226206 (4.0 mg/kg, i.v.), failed to affect the influence of citalopram upon DRN firing: vehicle + citalopram, inhibitory dose $\mathrm{S}_{50}\left(\mathrm{ID}_{50}\right)$ in $\mu \mathrm{g} / \mathrm{kg}$, $\mathrm{i} . \mathrm{v}=66.4 \pm 8.0 v s$ GR226206 + citalopram, $\mathrm{ID}_{50}=71.0 \pm 9.2$, $P>0.05$. By analogy to citalopram, fluoxetine blocked the activity of serotonergic perikarya. GR205171 dose-dependently (1.0-4.0 mg/kg, i.v.) displaced the dose-response curve of fluoxetine to the right. The effects of fluoxetine alone and of fluoxetine plus GR205171 were blocked by WAY100635. Further, GR226206 (4.0 mg/kg, i.v.) failed to affect the influence of fluoxetine: vehicle + fluoxetine, $\mathrm{ID}_{50}$ in $\mu \mathrm{g} / \mathrm{kg}, \quad$ i.v $=280.5 \pm 45.6$ vs GR226206+fluoxetine, $\mathrm{ID}_{50}=216.7 \pm 25.6, P>0.05$.

\section{Influence of GR205171 Upon Inhibition of Serotonergic} Neurones by $5-\mathrm{HT}_{1 \mathrm{~A}}$ Agonists

The 5-HT ${ }_{1 \mathrm{~A}}$ partial agonist, S15535 (Gobert et al, 1995; Millan et al, 1997a,b; Lejeune and Millan, 2000), dose dependently reduced the firing rate of DRN neurones (Figure 4). Its dose-response curve was shifted to the right by GR205171 (4.0 mg/kg, i.v.). This effect was expressed stereospecifically in that GR226206 $(4.0 \mathrm{mg} / \mathrm{kg}$, i.v.) failed to influence the decrease in DRN firing rate induced by S15535. In contrast, GR205171 (4.0) did not modify the inhibitory influence of the weak $5-\mathrm{HT}_{1 \mathrm{~A}}$ partial agonist, (-)-pindolol (Newman-Tancredi et al, 1998), nor of the 5$\mathrm{HT}_{1 \mathrm{~A}}$ agonists, 8-OH-DPAT and buspirone (Gobert et al, 1995; Lejeune et al, 1997; Newman-Tancredi et al, 1998), upon DRN firing rate. Actions of all 5- $\mathrm{HT}_{1 \mathrm{~A}}$ agents were antagonized by WAY100635 (0.1 mg/kg, i.v.).

\section{Influence of GR205171 Upon the Modulation of FCX Levels of Monoamines By 5-HT $1 \mathrm{~A}$ Agonists}

S15535 decreased levels of 5-HT in the FCX of freelymoving rats, and increased levels of DA and NA (Figure 5).
The inhibitory influence of S15535 upon 5-HT levels was not affected by GR205171. Interestingly, coadministration of GR205171 and S15535 was accompanied by a more pronounced elevation in levels of DA and NA than for either drug alone. 8-OH-DPAT also decreased 5-HT levels in FCX while increasing the levels of DA and NA. In the presence of GR205171, the reduction in 5-HT levels provoked by $8-\mathrm{OH}-\mathrm{DPAT}$ was unaffected, whereas the elevation in DA and NA was facilitated.

\section{Enhancement by GR205171 of the Antidepressant Action of Citalopram in the Forced Swim Procedure in Mice}

In the mice FS test, citalopram decreased the duration of immobility, whereas GR205171 had no effect up to $40.0 \mathrm{mg} /$ $\mathrm{kg}$, i.p. (Figure 6). In the presence of GR205171 (40.0), however, a subactive dose of citalopram (2.5) significantly decreased immobility. This effect was not observed with GR226206 (40.0), which was inactive alone. Lower doses (2.5 and 10.0) of GR205171 did not influence the effect of citalopram (2.5) upon immobility (s): vehicle + citalopram, $154.7 \pm 11.1(N=20)$ vs GR205171 (2.5) + citalopram (2.5), $145.0 \pm 19.7(N=8), P>0.05$ and $v s$ GR205171 $(10.0)+$ citalopram (2.5), $128.6 \pm 18.2(N=12), P>0.05$.

Lack of Enhancement by GR205171 of the Facilitatory Influence of Citalopram Upon Locomotor Activity in Mice

Citalopram (10.0 mg/kg, s.c.) increased locomotor activity in mice (Table 3 ). This action was dose-dependently (2.5-40.0 mg/kg, i.p.) attenuated by GR205171. Locomotor activity was not significantly modified by GR205171 alone. 

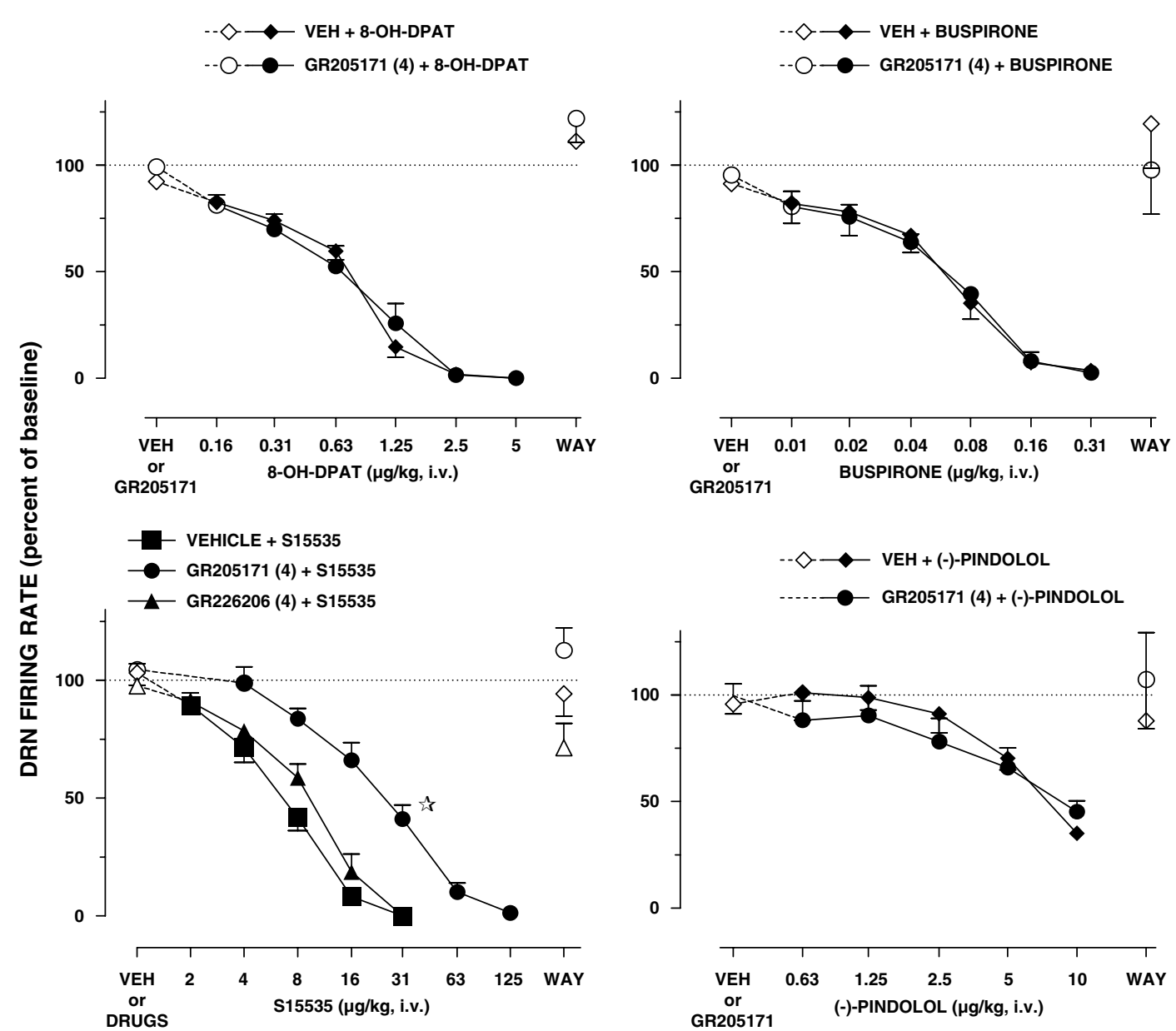

Figure 4 Influence of GR205 I7I on the inhibition of serotonergic neurones by the 5-HT IA agonists, SI5535, (-)-pindolol, 8-OH-DPAT and buspirone, in anesthetized rats. VEH, vehicle; WAY, WAY 100635. Data are means \pm SEMs; N $=5-7$ per value. Two-way ANOVA as follows. Vehicle + SI5535 vs GR205I7I (4) +SI5535, $F(8, I 04)=8.6, P<0.01$; vehicle $+S I 5535$ vs GR226206 (4) +SI5535, F(8,72) $=1.0, P>0.05$; vehicle + ( -$)$-pindolol vs GR205I7I (4) + (-)-pindolol, F(6,42)=0.6, P>0.05; vehicle + 8-OH-DPAT vs GR205 I 7 I (4) + 8-OH-DPAT, F $(6,72)=1.3, P>0.05 ;$ vehicle + buspirone vs GR205 I7I (4) + buspirone, $F(7,63)=0.4, P>0.05$. Asterisk indicates significance $(P<0.05)$ of GR205 I II-treated groups vs vehicle-treated groups.

\section{Enhancement by GR205171 of the Actions of Citalopram in the Ultrasonic Vocalization Procedure in Rats}

Citalopram dose-dependently decreased the duration of fear-induced USV in rats, though significance was obtained only for the highest dose tested $(10.0 \mathrm{mg} / \mathrm{kg}$, s.c.) (Figure 7). A similar profile was obtained with GR205171 $(40.0 \mathrm{mg} / \mathrm{kg}$, i.p.). GR226206 was inactive up to $40.0 \mathrm{mg} / \mathrm{kg}$, i.p. In the presence of GR205171 (10.0, i.p.), a subactive dose of citalopram (5.0, s.c.) significantly decreased USV, an effect not observed in the presence of GR226206 (40.0, i.p.).

\section{Additive Inhibition by GR205171 and Citalopram of Light-Induced Phase Advances in Circadian Wheel Running Rhythms in Hamsters}

A 10-min light pulse advanced circadian rhythms by $1.6 \pm 0.1 \mathrm{~h}$ following vehicle (Table 4). Citalopram $(5 \mathrm{mg} /$ $\mathrm{kg}$, i.p.) and GR205171 (5.0 mg/kg, i.p) alone did not influence light-induced phase advances. In contrast, combination of these doses significantly inhibited the effect of light $(-47 \%)$. Further, citalopram $(10.0 \mathrm{mg} / \mathrm{kg})$ and GR205171 $(20.0 \mathrm{mg} / \mathrm{kg})$ significantly inhibited the effect of light by -40 and $-70 \%$, respectively. When injected simultaneously, the combination inhibited the effect of light by $60 \%$.

Blockade by GR205171 of the Facilitation by Fluoxetine of Fear-Induced Foot-Tapping in Gerbils

In animals without fear conditioning (ie not submitted to shocks during the acquisition session), fluoxetine $(40.0 \mathrm{mg} /$ $\mathrm{kg}$, i.p.) did not induce foot tapping (Figure 8). In contrast, in fear-conditioned gerbils (submitted to shocks), fluoxetine dose-dependently induced foot tapping at doses of 20.0 and $40.0 \mathrm{mg} / \mathrm{kg}$, i.p. The dose of $40.0 \mathrm{mg} / \mathrm{kg}$, i.p. was selected for antagonist studies. GR205171 $(0.16 \mathrm{mg} / \mathrm{kg}$, i.p. $)$ blocked the effect of fluoxetine $(40.0 \mathrm{mg} / \mathrm{kg}$, i.p.) upon fear-conditioned foot tapping whereas GR226206 was inactive.

\section{Blockade by GR205171 of the Anxiogenic Actions of Citalopram in the Social Interaction Test in Rats and Gerbils}

Citalopram reduced the duration of SI between unfamiliar rats and gerbils exposed to a novel environment (Figure 9). 

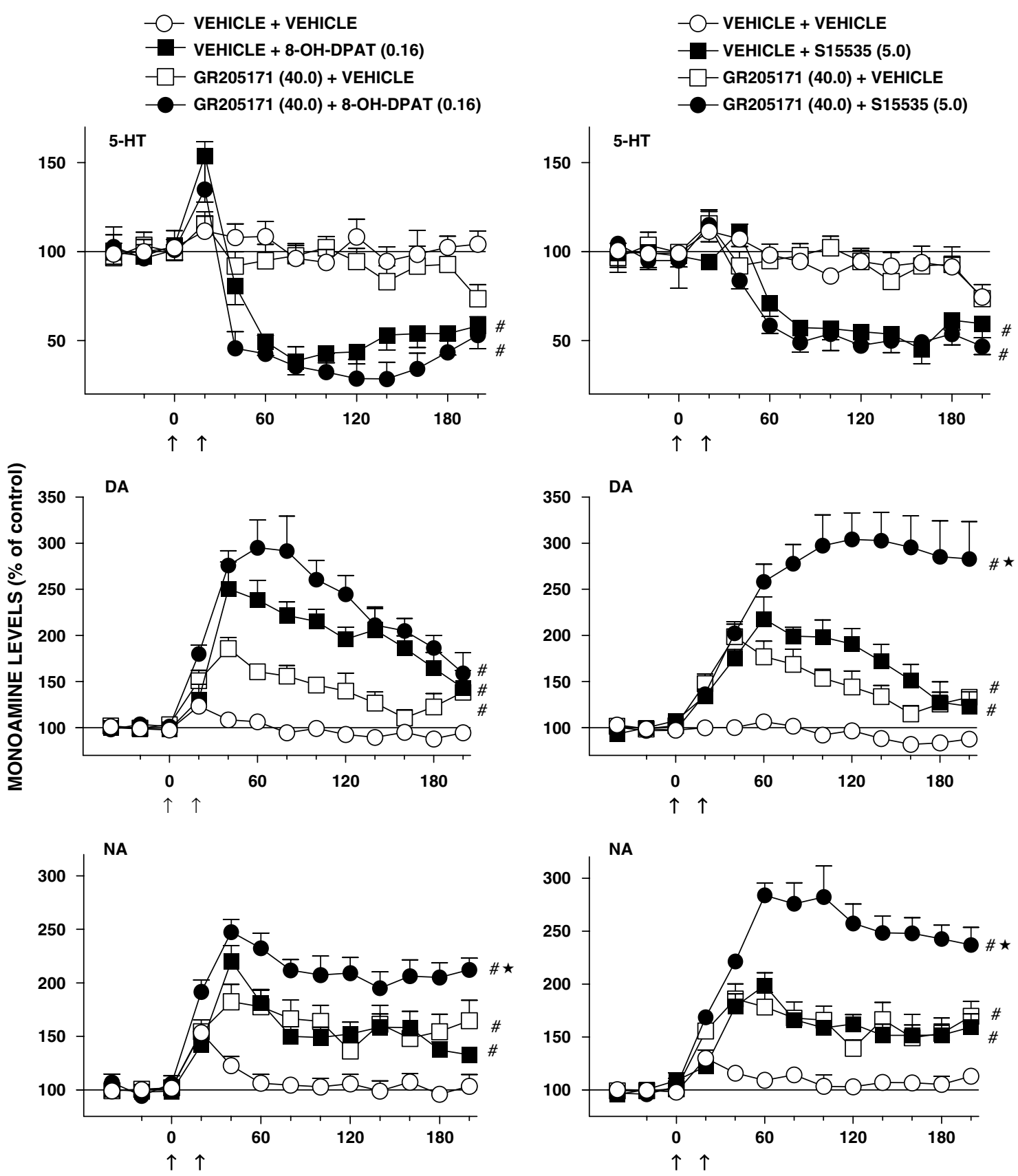

TIME (MIN)

Figure 5 Influence of GR205 I7I upon the modulation of frontocortical levels of monoamines by the 5-HTIA agonists, SI5535 and 8-OH-DPAT, in freely moving rats. Serotonin (5-HT), dopamine (DA), and noradrenaline (NA) levels are expressed relative to basal values defined as $100 \%$ (see legend of Figure I). Data are means \pm SEMs; $N=5-9$ per value. Arrows denote the injection of drugs. ANOVA as follows. SI5535, 5-HT: SI5535, F(I, II) $=50.8$, $P<0.0 I$; GR205I7I, $F(I, I 5)=0.2, P>0.05$ and interaction, $F(I, 8)=3.0, P>0.05 ; D A: S I 5535, F(I, I 2)=49.3, P<0.0 I ; G R 205 I 7 I,(I, I 6)=3 I .3, P<0.0 I$ and interaction, $F(I, 8)=12.7, P<0.0 I$ and $N A$ : SI5535, $F(I, I 2)=59.8, P<0.01$; GR205I7I, $(I, \mid 6)=29.3, P<0.0 \mid$ and interaction, $F(I, 8)=30.5$,

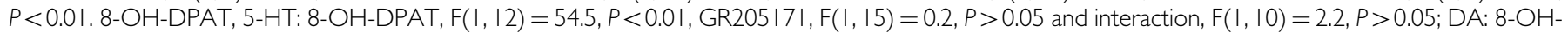
DPAT, $F(I, I 3)=89.2, P<0.0 I$; GR205I7I, $(I, I 6)=31.3, P<0.0 I$ and interaction, $F(I, I I)=2.6, P>0.05$ and $N A: 8-O H-D P A T, F(I, I 3)=46.3$, $P<0.0$ I; GR205 I 7I, $(I, I 6)=29.3, P<0.01$ and interaction, $F(I, I I)=14.8, P<0.01$. Significance $(P<0.05)$ of drug-treated groups vs vehicle-treated groups is indicated by ${ }^{\#}$, and the significance $(P<0.05)$ of GR205 I7I/8-OH-DPAT or GR205I7I/SI5535-treated groups vs vehicle/8-OH-DPAT- or vehicle/ SI5535-treated groups is indicated by asterisks.

In contrast, GR205171 alone did not modify the duration of SI in either species. However, GR205171 $(10.0 \mathrm{mg} / \mathrm{kg}$, i.p. in rat, and 0.63 in gerbils) antagonized the anxiogenic effect of citalopram. Conversely, GR226206 was inactive.
Influence of RP67580 Upon Neurochemical and Antidepressant Actions of Citalopram

The $\mathrm{NK}_{1}$ antagonist, $\mathrm{RP} 67580$ (40.0 mg/kg, i.p.), potentiated citalopram-induced increases in 5-HT levels in FCX. It also 

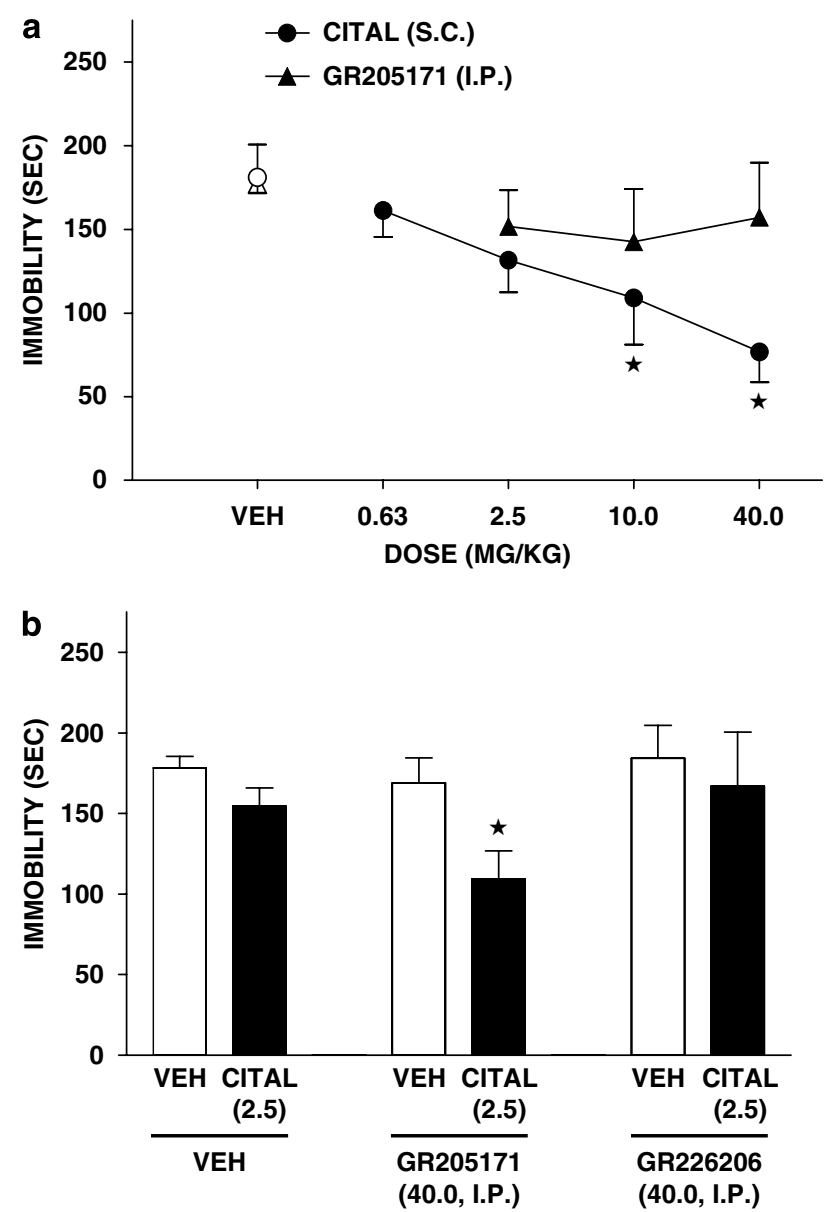

Figure 6 Enhancement by GR205 I7I of the antidepressant action of citalopram in the forced swim procedure in mice. VEH, vehicle and CITAL, citalopram. (a) Dose-dependent reduction of immobility by citalopram as compared to GR205 I7I; (b) stereospecific enhancement by GR205I7I as compared to its active distomer, GR226206, of the action of citalopram. Data are means \pm SEMs $(N=7-20)$. (a) One-way ANOVA as follows: citalopram, $F(4,30)=5.5, P<0.01$; GR205I7I, $F(3,20)=0.4, P>0.05$. Asterisks indicate significance of differences to respective vehicle values in Dunnett's test. (b) Two-way ANOVA as follows: citalopram, $F(I, 75)=5 . I$, $P<0.05 ; \quad G R 205171, \quad F(1,75)=11.6, \quad P<0.01$ and interaction, $F(I, 75)=2.2, P>0.05 ; G R 226206, F(I, 55)=0.5, P>0.05$ and interaction, $F(I, 55)=0.2, P>0.05$. The asterisk indicates significance of differences in Dunnett's test vs vehicle/vehicle values. $* P<0.05$.

mimicked GR205171 in elevating levels of DA and NA alone, but there was no difference between RP67580/citalopram vs RP67580/vehicle and vehicle/citalopram values (Table 1). In the FS test, the action of RP67580 (20.0 mg/kg, i.p.) and citalopram $(2.5 \mathrm{mg} / \mathrm{kg}$, s.c. $)$ together was greater $(P<0.05)$ than RP67580 or citalopram alone: vehicle/vehicle (s), $178.7 \pm 10.6$; citalopram/vehicle, $168.3 \pm 9.0$; vehicle/ RP67580, $168.3 \pm 9.0$ and citalopram/ RP67580, 122.4 \pm 17.0.

\section{DISCUSSION}

\section{Potentiation by GR205171 of the Influence of Citalopram Upon 5-HT Levels}

Several arguments underpin the specificity of the facilitation by GR205171 of increases in levels of 5-HT elicited by citalopram in FCX. First, GR205171 is a highly selective antagonist of $\mathrm{NK}_{1}$ receptors and expressed its actions across a
Table 3 Influence of GR205 I7I Upon the Induction of Locomotion in Mice by Citalopram

Locomotor counts

\begin{tabular}{ll}
\hline Vehicle+vehicle & $400.0 \pm 28.7$ \\
GR205 I7I (2.5)+vehicle & $404.2 \pm 33.8$ \\
GR205 I7I ( I0.0)+vehicle & $405.7 \pm 24.7$ \\
GR205 I7I (40.0)+vehicle & $298.8 \pm 35$. I \\
Vehicle+citalopram (0.63) & $494.5 \pm 32$. I \\
GR205 I7I (2.5)+citalopram (0.63) & $439.0 \pm 30.6$ \\
GR205 I7I ( I0.0)+citalopram (0.63) & $429.5 \pm 49.5$ \\
GR205 I7I (40.0)+citalopram (0.63) & $320.8 \pm 30.2 *$ \\
Vehicle+citalopram (I0.0) & $521.0 \pm 43.0^{\#}$ \\
GR205 I7I (2.5)+citalopram (I0.0) & $584.3 \pm 32.0$ \\
GR205 I7I (I0.0)+citalopram (I0.0) & $562.5 \pm 49.3$ \\
GR205 I7I (40.0)+citalopram (I0.0) & $422.3 \pm 32.4$ \\
\hline
\end{tabular}

Doses in $\mathrm{mg} / \mathrm{kg}$. Data are means $\pm \mathrm{SEMs}$ and represent locomotor counts during 10 min. $N=6-7$ per value. ANOVA as follows. Citalopram (0.63),

$F(I, I 0)=4.6, P>0.05$; influence of GR205I7I, $F(3,22)=2.8, P>0.05$ and interaction, $F(3,18)=4.9, P<0.05$. Citalopram $(I 0.0), F(I, I I)=5.8, P<0.05$; influence of $G R 205 \mathrm{I} 7 \mathrm{I}, F(3,22)=2.8, P>0.05$ and interaction, $F(3,2 \mathrm{I})=3.3$, $P<0.05$.

\#Significance $(P<0.05)$ of citalopram-treated group vs vehicle-treated group; *significance $(P<0.05)$ of GR205 I / / citalopram-treated group vs vehicle/ citalopram-treated group.

dose range identical to that exerting other cerebral actions in rodents (Gardner et al, 1996; Millan et al, 2001b; Rupniak et al, 2001; Lejeune et al, 2002; Brocco et al, 2008). Further, its actions were stereospecific in as much as its less active isomer, GR226206, was ineffective. Second, the influence of GR205171 was reproduced with another selective $\mathrm{NK}_{1}$ antagonist, RP67580 (Garret et al, 1991; Gobbi et al, 2007), and GR205171 also stereospecifically augmented the influence of fluoxetine upon 5-HT levels in FCX. Third, GR205171 potentiates paroxetine-induced increases in extracellular levels of 5-HT in the FCX of mice (Guiard et al, 2004). Fourth, herein, GR205171 also enhanced the action of citalopram in four further structures receiving serotonergic input from the DRN and controlling affect (Millan, 2003, 2006): hippocampus, BLA, nucleus accumbens, and striatum. Fifth, the enhancement of SSRI-induced increases in FCX levels of 5-HT by GR205171 was paralleled by its suppression of their inhibition of DRN-localized serotonergic neurones. Finally, pharmacokinetic interactions are unlikely to be involved as: (1) two different $\mathrm{NK}_{1}$ antagonists facilitated the neurochemical effects of two different SSRIs; (2) compatible findings were acquired in electrophysiological studies using the i.v. route, a route which avoids first pass elimination in the liver; (3) certain responses to SSRIs were blocked by $\mathrm{NK}_{1}$ antagonists; (4) similar results were seen in mice using paroxetine (Chenu et al, 2006), and (5) genetic deletion of $\mathrm{NK}_{1}$ receptors likewise enhances the influence of SSRIs upon levels of 5-HT (Guiard et al, 2004, 2005).

\section{Integration at the Level of the DRN: Significance of $5-\mathrm{HT}_{1 \mathrm{~A}}$ Autoreceptors}

$\mathrm{NK}_{1}$ antagonists are unlikely to directly affect actions of SSRIs as GR205171 and RP67580 have negligible affinities 
a
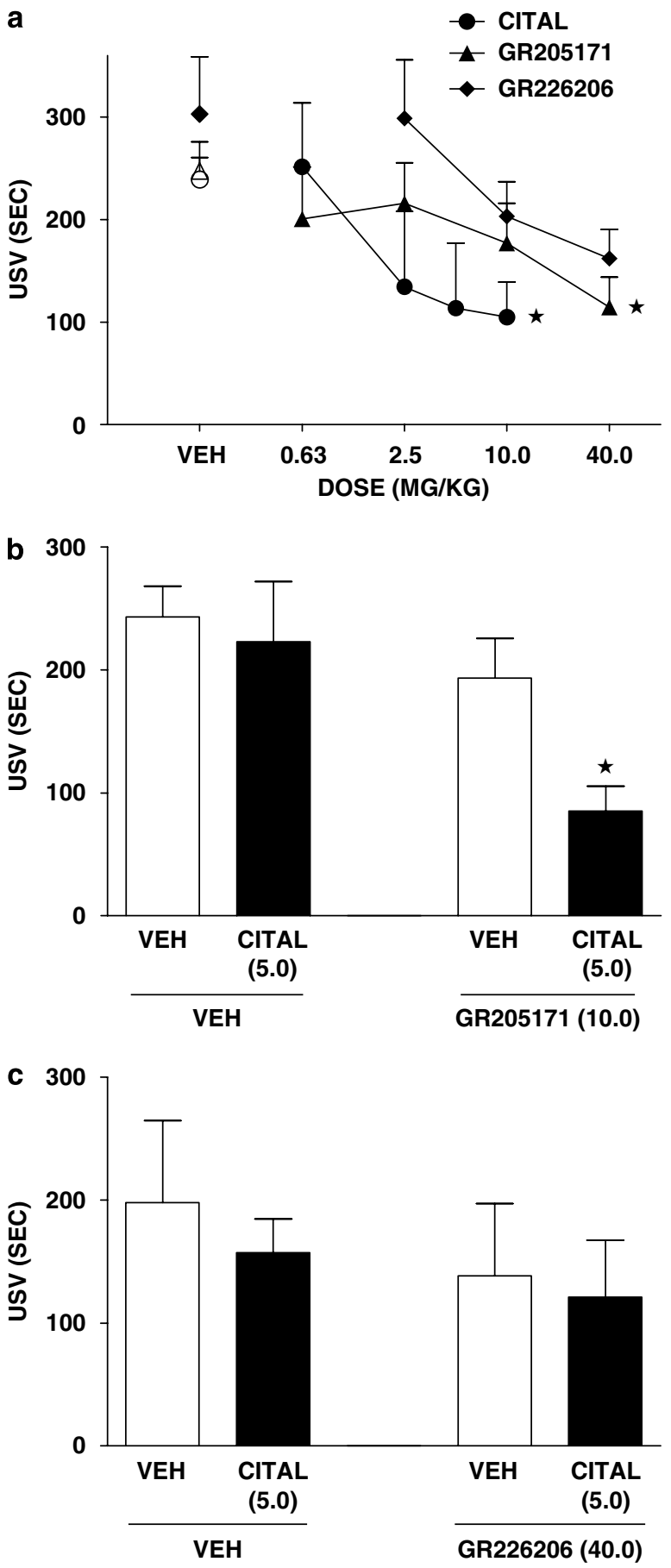

Figure 7 Enhancement by GR205 I7I of the actions of citalopram in the ultrasonic vocalization procedure in rats. $\mathrm{VEH}=$ vehicle and $\mathrm{Cl}$ $\mathrm{TAL}=$ citalopram. (a) Dose-dependent reduction of USV by CITAL and GR205 I7I as compared with its less active distomer, GR226206. (b, c) Stereospecific enhancement by GR205I7I of the action of CITAL. Data are means \pm SEMs; $N=5-15$ per value. (a) ANOVA as follows: CITAL, $F(4,5 I)=3.0, P<0.05 ; G R 205 I 7 I, F(4,47)=1.8, P>0.05$ and $G R 226206$, $F(3,21)=2.3, P>0.05$. Asterisks indicate significance of differences to respective $\mathrm{VEH}$ values in Dunnett's test. (b, c) ANOVA as follows. (b) CITAL, $F(I, 29)=3.8, P>0.05 ; G R 205|7|, F(I, 29)=\mid 8.9, P<0.01$ and interaction, $F(I, 29)=1.8, P<0.05$. (c) CITAL, $F(I, \mid 4)=0.3, P<0.05$, GR226206, $F(I, \mid 4)=0.8, P>0.05$ and interaction, $F(I, \mid 4)=0 . I, P>0.05$. The asterisk indicates significance of differences in Newman-Keuls test vs VEH/VEH values. ${ }^{*} P<0.05$.
Table 4 Additive Influence of Low Doses of GR205 17I and Citalopram Upon the Phase Advances in Circadian Wheel Running Rhythms Elicited by Light in Hamsters

\begin{tabular}{ll}
\hline & Phase advance (h) \\
\hline Vehicle+vehicle & $1.32 \pm 0.09$ \\
GR205 I7I (5.0)+vehicle & $1.13 \pm 0.13$ \\
Vehicle+citalopram (5.0) & $1.05 \pm 0.13$ \\
GR205 I7I (I0.0)+citalopram (5.0) & $0.70 \pm 0.10^{*}$ \\
Vehicle+vehicle & $1.58 \pm 0.13$ \\
GR205 I7I (20.0)+vehicle & $0.95 \pm 0.12^{*}$ \\
Vehicle+citalopram (I0.0) & $0.47 \pm 0.14 *$ \\
GR205 I7I (20.0)+citalopram (I0.0) & $0.60 \pm 0.12^{*}$ \\
\hline
\end{tabular}

Data are means \pm SEMs $(N=5-8)$. One-way ANOVA; interaction of citalopram $(5.0 \mathrm{mg} / \mathrm{kg})$ with GR205 I7I $(5.0 \mathrm{mg} / \mathrm{kg}), F(3,25)=6.3, P<0.01$ and interaction of citalopram $(10.0 \mathrm{mg} / \mathrm{kg})$ with GR205 $171(20.0 \mathrm{mg} / \mathrm{kg}), F(3,21)=13.5$,

$P<0.01$.

$* P<0.05$ vs vehicle/vehicle values in Student-Newman-Keuls test.

for 5-HT transporters $\left(\mathrm{pK}_{i}\right.$ values, <5.0), and do not modify the actions of SSRIs at synaptosomes in vitro (Lieb et al, 2005; Millan, MJ, unpublished observation). Antagonists at $5-\mathrm{HT}_{1 \mathrm{~B}}$ autoreceptors on serotonergic terminals enhances increases in 5-HT levels elicited by SSRIs (Gobert et al, 1997). However, GR205171 and RP67580 have no affinity for $5-\mathrm{HT}_{1 \mathrm{~B}}$ receptors, and this would not explain their abrogation of the inhibitory influence of SSRIs on serotonergic neurones in the DRN (Gardner et al, 1996; Millan et al, 2000). Rather, inhibitory 5- $\mathrm{HT}_{1 \mathrm{~A}}$ autoreceptors are localized on serotonergic perikarya, and $5-\mathrm{HT}_{1 \mathrm{~A}}$ antagonists likewise enhance increases in FCX levels of 5HT elicited by SSRIs (Gobert et al, 1997; Millan et al, 2000; Guilloux et al, 2006). Though GR205171 and RP67580 do not behave as $5-\mathrm{HT}_{1 \mathrm{~A}}$ antagonists $\left(\mathrm{pK}_{i}\right.$ values, <5.0; Gardner et al, 1996; Figure 5), it is important to consider the significance of $5-\mathrm{HT}_{1 \mathrm{~A}}$ autoreceptors.

In agreement with most studies of $\mathrm{NK}_{1}$ antagonists (Haddjeri and Blier, 2000; Conley et al, 2002; Lejeune et al, 2002; Guiard et al, 2005; Gobbi et al, 2007), GR205171 did not affect the spontaneous activity of DRN-localized serotonergic neurones. However, its reduction of the inhibitory influence of citalopram and fluoxetine upon DRN firing mimics the effects of chronic administration of $\mathrm{NK}_{1}$ antagonists (Haddjeri and Blier, 2001; Guiard et al, $2005)$, and of genetic elimination of $\mathrm{NK}_{1}$ receptors in mice (Froger et al, 2001; Santarelli et al, 2001; Gobbi et al, 2007). A subpopulation (some $30 \%$ ) of 5-HT neurones in the DRN bear $\mathrm{NK}_{1}$ receptors (Froger et al, 2001; Ma and Bleasdale, 2002; Lacoste et al, 2006), raising the possibility that $\mathrm{NK}_{1}$ antagonists (via signalling crosstalk) disrupt the inhibitory influence of SSRI-engaged 5- $\mathrm{HT}_{1 \mathrm{~A}}$ autoreceptors upon DRN firing. Indeed, the inhibitory influence of $5-\mathrm{HT}_{1 \mathrm{~A}}$ agonists on the DRN is blunted by chronic treatment with $\mathrm{NK}_{1}$ antagonists (Haddjeri and Blier, 2001; Guiard et al, 2005), and by genetic deletion of $\mathrm{NK}_{1}$ receptors (Froger et al, 2001; Santarelli et al, 2001). However, acute blockade of $\mathrm{NK}_{1}$ receptors does not generally desensitize $5-\mathrm{HT}_{1 \mathrm{~A}}$ autoreceptors (Blier et al, 2004; Guiard et al, 2007; Gobbi et al, 2007), and GR205171 did not modify the influence of 5- $\mathrm{HT}_{1 \mathrm{~A}}$ agonists on DRN firing rate in vitro (Guiard et al, 2005). 


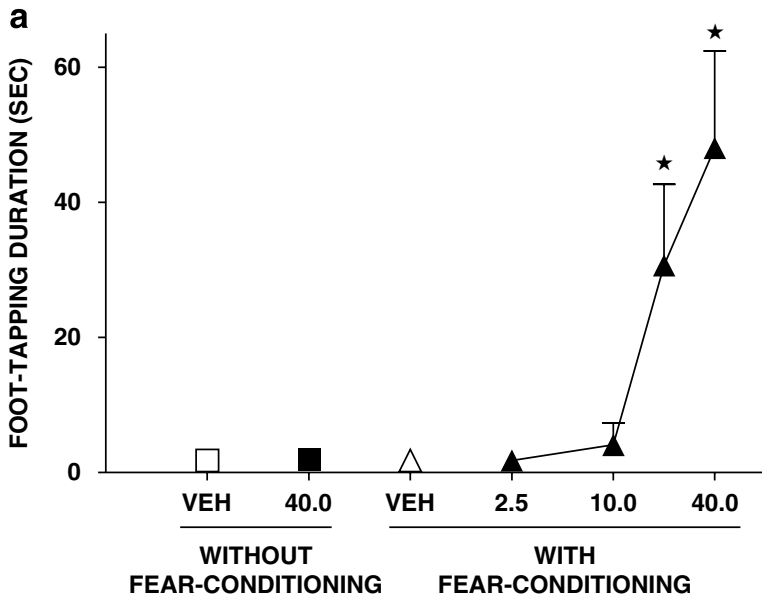

FLUOXETINE (MG/KG, I.P.)

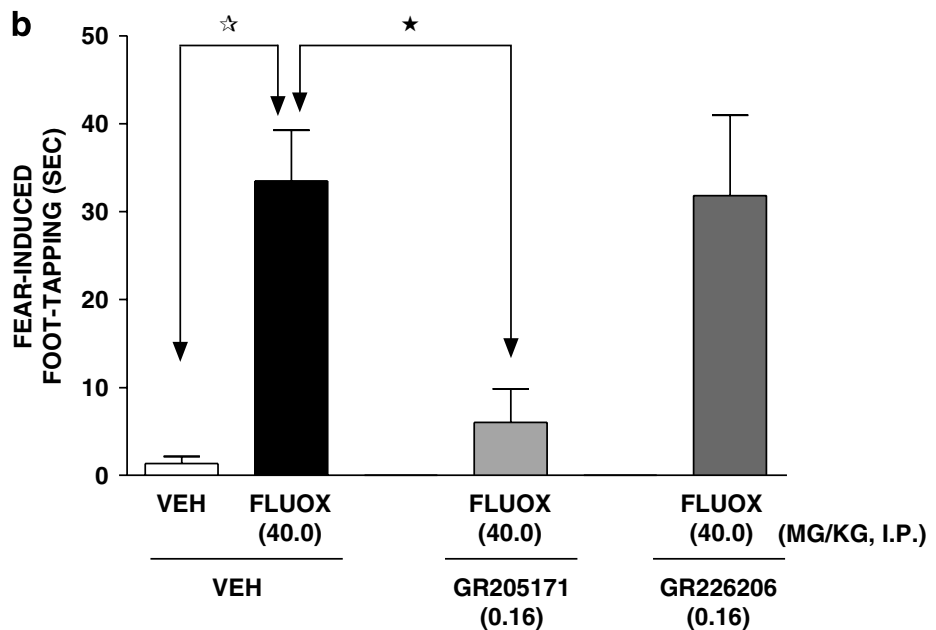

Figure 8 Blockade by GR205 I7I of the facilitation by fluoxetine of fear-induced foot tapping in gerbils. VEH=vehicle and FLUOX=fluoxetine. (a) Induction of foot tapping by FLUOX and (b) stereospecific blockade by GR205 I7I of the action of FLUOX. Data are means \pm SEMs; $N=4-10$ per values, ANOVA as follows. (a) FLUOX, F(3, I5)=6.6, P<0.05. Asterisks indicate significance of differences in Dunnett's test between fear-conditioning/FLUOX and fear-conditioning $N E H$ values. (b) Interaction, $F(2,35)=4.4, P<0.05$. The closed asterisk indicates significance of differences in Dunnett's test between VEH/FLUOX and GR205 I7I/FLUOX values and open asterisks, between fluoxetine and vehicle values. $* P<0.05$.

Correspondingly, the lack of influence of GR205171 upon the inhibition of DRN firing (Figure 4) by two $5-\mathrm{HT}_{1 \mathrm{~A}}$ agonists, 8-OH-DPAT and buspirone (Lejeune et al, 1997), suggests that it does not markedly affect the sensitivity of 5$\mathrm{HT}_{1 \mathrm{~A}}$ autoreceptors. Conversely, GR205171 attenuated the inhibitory influence of a lower efficacy (ca 30-40\% vs 5-HT) $5-\mathrm{HT}_{1 \mathrm{~A}}$ ligand, S15535 (Millan et al, 1997a, b; NewmanTancredi et al, 1998) upon DRN firing. Thus, this partial agonist may reveal a subtle alteration by $\mathrm{NK}_{1}$ receptor blockade of coupling at $5-\mathrm{HT}_{1 \mathrm{~A}}$ autoreceptors. However, changes in firing rate do not invariably translate into alterations in release (Gobert et al, 1995; Millan and Gobert, 1999; Millan et al, 2000; Artigas et al, 2001; Gobbi et al, 2007), and the reduction by S15535 (and 8-OH-DPAT) of 5HT release in FCX was not modified by GR205171. Moreover, GR205171 did not modify the influence on serotonergic neurones of (-)-pindolol, a low efficacy 5$\mathrm{HT}_{1 \mathrm{~A}}$ ligand (ca 20\%) which only submaximally decreases firing rate (Newman-Tancredi et al, 1998; Millan and Gobert, 1999; Guilloux et al, 2006). Recruitment of postsynaptic $5-\mathrm{HT}_{1 \mathrm{~A}}$ receptors in FCX triggers long-loop, inhibitory feedback to serotonergic cell bodies in raphe nuclei (Haddjeri et al, 2000; Celada et al, 2001; Sharp et al, 2007). However, they are unlikely to be involved in the activations of GR205171 as the sensitivity of postsynaptic 5$\mathrm{HT}_{1 \mathrm{~A}}$ receptors is unaffected by $\mathrm{NK}_{1}$ antagonists (Froger et al, 2001; Haddjeri and Blier, 2001; Santarelli et al, 2001). Further, though microinjection of substance P into the FCX suppressed 5-HT release, this action did not involve frontocortical 5- $\mathrm{HT}_{1 \mathrm{~A}}$ receptors (Guiard et al, 2007).

\section{Possible Involvement of Gabaergic, Glutatamergic, and Adrenergic Mechanisms}

$\mathrm{NK}_{1}$ receptors have been identified on GABAergic neurones surrounding 5 -HT cell bodies in the DRN, and studies in the septum and cortex suggest that $\mathrm{NK}_{1}$ receptor antagonists may indirectly excite serotonergic neurones via a reduction of inhibitory GABAergic tone (Sloviter et al, 2001; Ma and Bleasdale, 2002; Stacey et al, 2002; Szeidemann et al, 1995; Ebner et al, 2008). This would enhance their responsiveness to SSRIs, by analogy to $\mathrm{GABA}_{\mathrm{B}}$ antagonists (Millan, 2006; Cremers et al, 2007). Glutamatergic terminals targeting serotonergic DRN neurones also bear $\mathrm{NK}_{1}$ receptors (Liu et al, 2002; Valentino et al, 2003), and their stimulation by intraraphe perfusion of substance $P$ enhances local release of 5-HT via recruitment of AMPA receptors (Guiard et al, 2007). This results in a (delayed) decrease in cortical 5-HT release due to activation of $5-\mathrm{HT}_{1 \mathrm{~A}}$ autoreceptors. That is, in line with the present observations, $\mathrm{NK}_{1}$ receptors are 'upstream' of $5-\mathrm{HT}_{1 \mathrm{~A}}$ autoreceptors. Interestingly, by analogy to lateral septum (Ebner et al, 2008), frontocortical perfusion of substance P suppressed local release of 5-HT in mice, an effect blocked by GR205171 and absent in mice lacking $\mathrm{NK}_{1}$ receptors (Guiard et al, 2007). Thus, $\mathrm{NK}_{1}$ antagonists conceivably also enhance SSRI-induced increase in 5-HT levels by actions in the FCX and other structures innervated by the DRN. Finally, Gobbi et al (2007) found that functionally intact adrenergic terminals are essential for the facilitatory influence of $\mathrm{NK}_{1}$ receptor antagonists upon DRN firing. This is coherent with the excitatory impact of $\mathrm{NK}_{1}$ receptor blockade upon electrical activity of LC-derived adrenergic neurones (Millan et al, 2001b; Gobbi et al, 2007).

\section{Influence of $\mathrm{NK}_{1}$ Receptor Blockade Upon NA and DA Levels}

Elevations in levels of NA in FCX are seen in mice genetically deprived of $\mathrm{NK}_{1}$ receptors and are elicited by $\mathrm{NK}_{1}$ antagonists in parallel with an excitation of the LC (Millan et al, 2001b; Maubach et al, 2002; Blier et al, 2004; Ebner and Singewald, 2007; Gobbi et al, 2007). Correspondingly, GR205171 and RP67580 increased extracellular levels 
RAT
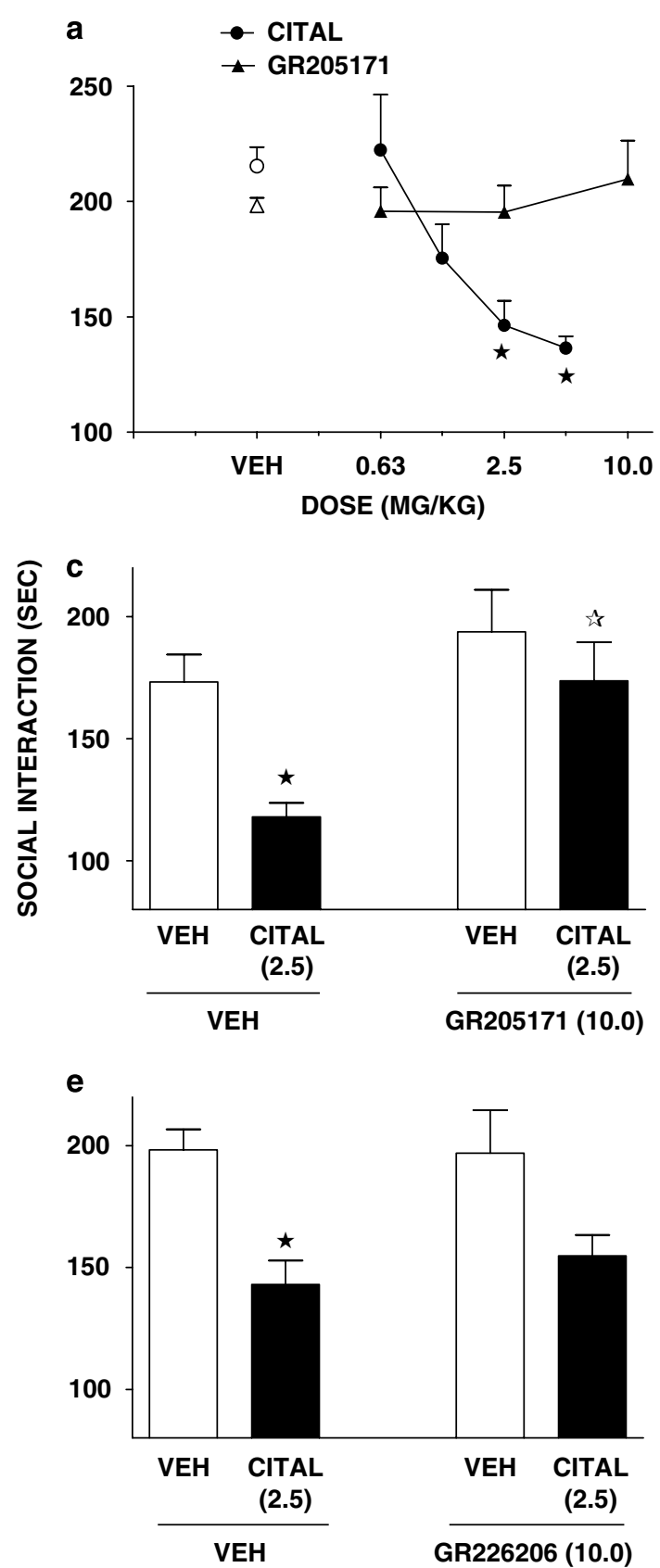

GERBIL
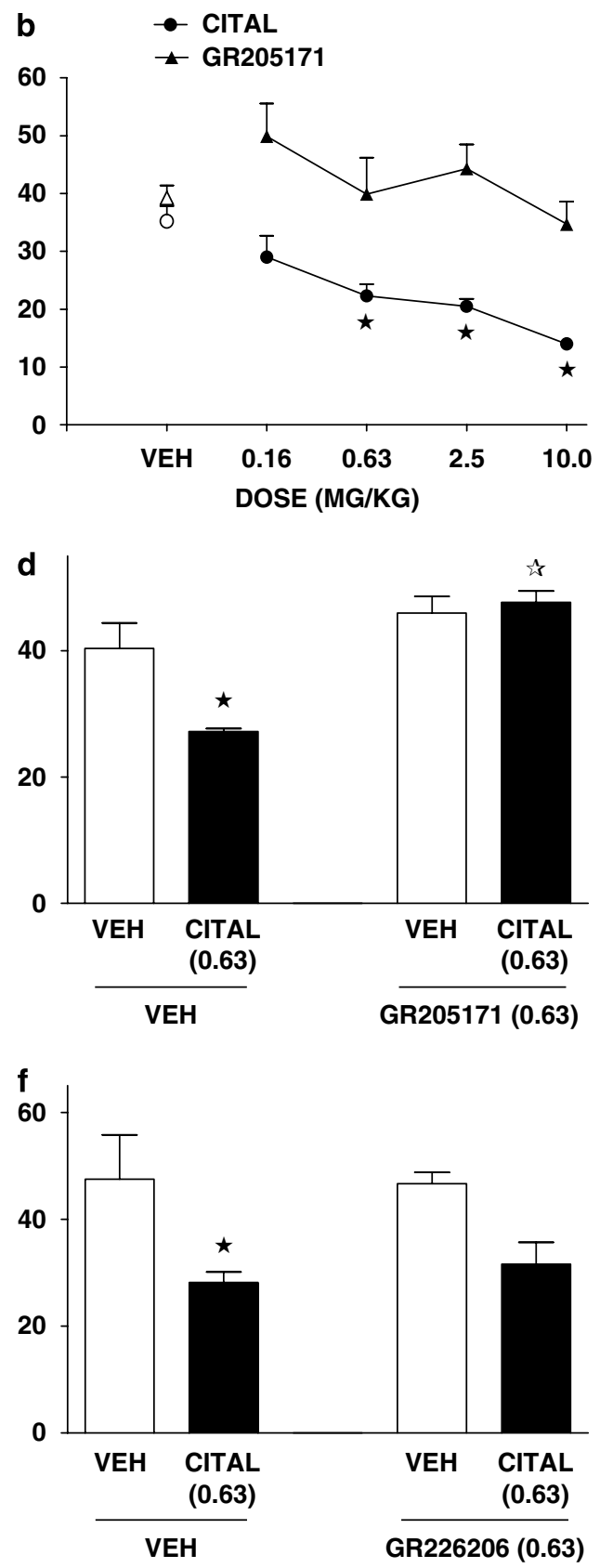

Figure 9 Blockade by GR205I7I of the anxiogenic actions of citalopram in the social interaction test in rats and gerbils. VEH=vehicle and $\mathrm{CITAL}=$ citalopram. $(\mathrm{a}, \mathrm{b})$ Dose-dependent reduction of SI by CITAL as compared with GR205 I7I in rats and gerbils, respectively, and (c- $f$ ) stereospecific blockade by GR20517I of the action of CITAL. Data are means \pm SEMs; $N=5-18$ per value. (a, b) ANOVA as follows: CITAL in rats, F(4,38) $=10.6$, $P<0.0$ I, GR205I7I in rats, $F(3,22)=0.4, P>0.05$, CITAL in gerbils, $F(4,26)=13.9, P<0.01$ and GR205I7I in gerbils, $F(4,33)=1.6, P>0.05$. Asterisks indicate significance of differences to respective vehicle values in Dunnett's test. (c-f) ANOVA as follows. (c) CITAL, F(I, I8) =7.I, P<0.05; GR205I7I, $F(I, I 8)=7.3, P<0.05$ and interaction, $F(I, I 8)=1.6, P>0.05$. (d) CITAL, $F(I, I 7)=5.3, P<0.05$; GR205 I II, $F(I, \mid 7)=27.2, P<0.0 \mid$ and interaction, $F(I, I 7)=8.9, P<0.01$. (e) CITAL, $F(I, 25)=15.4, P<0.0 I ; G R 226206, F(I, 25)=0.2, P>0.05$ and interaction, $F(I, 25)=0.3, P>0.05$. (f) $C I T A L$, $F(I, 19)=13.6, P<0.01 ; G R 226206, F(I, 19)=0.2, P>0.05$ and interaction, $F(I, I 9)=0.4, P>0.05$. Closed asterisks indicate significance of differences in Newman-Keuls test between VEH/CITAL and VEH/NEH values and open asterisks, between NK antagonist/CITAL and VEH/CITAL values. $* P<0.05$.

of NA in FCX, as well as in the BLA and hippocampus - structures likewise innervated by the LC (Millan et al, 2001b). The VTA possess a high density of $\mathrm{NK}_{1}$ sites (Lessard and Pickel, 2005), and electrical activity of VTAlocalized dopaminergic neurons is accelerated by blockade of $\mathrm{NK}_{1}$ receptors, an effect accompanied by increases in DA levels in FCX (Lejeune et al, 2002). This finding was confirmed herein for GR205171, reproduced with RP67580 and extended to the BLA. Interestingly, neither agent affected DA levels in striatum or nucleus accumbens which are innervated by different subpopulations of dopaminergic cell bodies: that is, substantia nigra pars compacta (nigrostriatal) and paranigral-VTA (mesolimbic) vs parabrachial-VTA (mesocortical), respectively (Lejeune et al, 
1997; Lejeune and Millan, 2000). These observations accord with the differential control of these clusters of dopaminergic neurons (Millan et al, 2000; Adell and Artigas, 2004; Alex and Pehek, 2007), including 5- $\mathrm{HT}_{1 \mathrm{~A}}$ receptor agonism which disinhibits VTA-derived mesocortical dopaminergic and LC-derived adrenergic pathways via GABAergic interneurones (Millan et al, 2000; Invernizzi et al, 2007). Interestingly, 8-OH-DPAT and S15535-induced elevations in FCX levels of DA and NA (Millan et al, 1997b; Gobert et al, 1995, 1999), were additive to those of GR205171. This indicates that $5-\mathrm{HT}_{1 \mathrm{~A}}$ agonism and $\mathrm{NK}_{1}$ receptor blockade offer complementary strategies for improvement of affect (Lucki et al, 1994; Millan, 2003, 2006; Czeh et al, 2006). GR205171 and fluoxetine likewise additively augmented dialysate levels of NA and DA in FCX, suggesting complementary mood-elevating properties independent of 5-HT (Millan et al, 2000). Accordingly, association of $\mathrm{NK}_{1}$ receptor blockade with high doses of SSRIs, with the NA reuptake inhibitor, reboxetine, or with 5-HT/NA reuptake inhibitors like venlafaxine (Morilak and Frazer, 2004; Millan, 2006), may lead to more pronounced elevations in NA levels in FCX and improved antidepressant efficacy.

\section{Enhancement of the Effects of Citalopram in a Forced Swim Procedure}

Addition of GR205171 to a subactive dose of citalopram led to a significant antidepressant effect, an action exerted stereoselectively vs GR226206. These observations support the finding of a recent study of GR205171 and paroxetine by Chenu et al (2006)-though stereospecificity was not demonstrated. Apart from the hippocampus, the septum is implicated in antidepressant actions of SSRIs (Sheehan et al, 2004; Millan, 2006), and $\mathrm{NK}_{1}$ antagonists may enhance 5 -HT release in this region via inhibition of GABAergic interneurons (Szeidemann et al, 1995; Millan, 2006; Ebner et al, 2008). As GR205171 blunted the increase in locomotor activity elicited by citalopram herein (Table 3 ), potentiation of the actions of citalopram in the FS procedure is unlikely to reflect stimulation of motor behavior (Redrobe and Bourin, 1998; Brocco et al, 2006). Likewise, augmentation of paroxetine-induced decreases in immobility in the FS test occurred at a dose of GR205171 which did not increase its motor actions (Chenu et al, 2006).

\section{Enhancement of the Action of Citalopram in the Stress-Related Ultrasonic Vocalization Test}

Exposure of rats to stress elicits USVs at a characteristic frequency of $22 \mathrm{kHz}$ (De Vry et al, 1993; Sánchez, 2003). This model is sensitive to SSRIs and, accordingly, citalopram reduced USVs (Molewijk et al, 1996; Sanchez and Meier, 1997; Millan et al, 2001a; Sánchez, 2003). Curiously, actions of $\mathrm{NK}_{1}$ antagonists have not, as yet been documented. In fact, periaqueductal grey administration of substance $P$ reduced USVs elicited by isolation in rats (Bassi et al, 2007), but $\mathrm{NK}_{1}$ antagonists suppress isolation-induced (nonultrasonic) vocalizations in juveniles via actions in the amygdala (Molewijk et al, 1996; Rupniak et al, 2000; Brocco et al, 2008). This observation is coherent with the present finding that GR205171 attenuates stress-induced USVs. Moreover, though the difference in potency between
GR205171 and GR226206 was, for unclear reasons, less marked in this procedure than for other paradigms, only GR205171 potentiated the inhibitory influence of citalopram on USVs. These data suggest that $\mathrm{NK}_{1}$ receptor blockade may enhance the abrogation of stress-elicited behaviors by SSRIs.

\section{Additive Influence on Circadian Rhythms}

A normalization of perturbed diurnal scheduling of behavior is implicated in the therapeutic actions of certain antidepressants (Duncan, 1996; Millan, 2006). Light-induced phase shifts of activity rhythms in hamsters are blunted by several classes of antidepressant, including SSRIs (Millan, 2006; Gannon and Millan 2007). They likely act in the suprachiasmatic nucleus, which contains a high density of 5-HT transporters on serotonergic terminals originating in the median raphe nucleus (Legutko and Gannon, 2001). Intriguingly, a similar suppression of lightinduced circadian phase-shifts is seen with $\mathrm{NK}_{1}$ antagonists, which act upstream in the raphe to intensify serotonergic input to the suprachiasmatic nucleus (Valentino et al, 2003; Gannon and Millan, 2005). Consistent with contrasting mechanisms of action, subthreshold doses of citalopram and GR205171 additively prevented light-triggered phaseshifts. Accordingly, combined $\mathrm{NK}_{1}$ receptor blockade and suppression of 5-HT reuptake may mutually restore circadian rhythmicity in certain depressed patients.

\section{Blockade of the Anxiogenic Effects of Citalopram and Fluoxetine}

SSRIs elicits anxiogenic effects in the SI procedure in rats, an observation extended herein to gerbils (Dekeyne et al, 2000; Millan, 2003). By contrast, $\mathrm{NK}_{1}$ receptor antagonists either fail to affect, or enhance, SI, probably dependent upon the degree of substance P release (File, 1997; Dekeyne et al, 2000; Varty et al, 2002; Millan, 2003; Brocco et al, 2008; Ebner et al, 2008). GR205171 stereospecifically abolished the reduction in SI elicited by citalopram in rats, and similar results were acquired in gerbils, a species in which $\mathrm{NK}_{1}$ receptors are potently blocked by GR205171 (Griffante et al, 2006; Engberg et al, 2007). Serotonin ${ }_{2 C}$ receptors in the hippocampus, amygdala and/or locus coeruleus mediate anxiogenic actions of SSRIs (Dekeyne et al, 2000; Millan 2003; Campbell and Merchant, 2003; Salchner and Singewald, 2006). However, GR205171 does not affect the reduction in SI provoked by $5-\mathrm{HT}_{2 \mathrm{C}}$ agonists (Dekeyne A, unpub. obs.), suggesting an action 'upstream' of $5-\mathrm{HT}_{2 \mathrm{C}}$ sites. These observations are supported by a further paradigm based on enhancement of fear-conditioned anxiety by SSRIs. Association of a mild aversive stimulus with fluoxetine triggers a characteristic foot-thumping response in gerbils (Millan, 2003; Rupniak et al, 2003; Burghardt et al, 2007; Brocco et al, 2008). By analogy to other $\mathrm{NK}_{1}$ antagonists (op. cit.), this behavior was stereospecifically abrogated by GR205171, supporting the contention that acute anxiogenic effects of SSRIs are tempered by $\mathrm{NK}_{1}$ receptor blockade. SSRI-induced nervousness reduces compliance, triggers early abandonment of therapy and is associated with a long delay to efficacy (Millan, 2003, 2006; Morilak and Frazer, 2004). The present observations suggest 
that $\mathrm{NK}_{1}$ receptor antagonists, which show anxiolytic properties in patients with major depression or social phobia (Kramer et al, 1998, 2004; Michelgard et al, 2007), may alleviate anxiogenic effects of SSRIs at the onset of therapy.

\section{General Discussion}

First, the present data show that the antidepressant efficacy of SSRIs is enhanced by blockade of $\mathrm{NK}_{1}$ receptors, yet that their acute anxiogenic actions are abrogated. Thus, the present observation support the association of SSRIs and selective $\mathrm{NK}_{1}$ antagonists and the development of mixed $\mathrm{NK}_{1}$ antagonists/5-HT reuptake inhibitors for treatment of depression and anxiety (Ryckmans et al, 2002; Chenu et al, 2006; Millan, 2006; Brocco et al, 2008). Second, association of GR205171 with fluoxetine led to additive increases in levels of NA and DA suggesting that interactions between $\mathrm{NK}_{1}$ antagonists and antidepressants may also involve dopaminergic and adrenergic mechanisms. GR205171 did not potentiate antidepressant actions of the NA reuptake inhibitor, desipramine (Chenu et al, 2006), and desipramine did not more markedly increase NA levels in $\mathrm{NK}_{1}$ knock-out mice (Herpfer et al, 2005). Nonetheless, it would be of interest to examine the influence of GR205171 upon actions of mixed 5-HT/NA reuptake inhibitors like venlafaxine, and the atypical agent, mirtazapine (Millan et al, 2000; Morilak and Frazer, 2004; Millan, 2006). This argument is underpinned by the marked elevation in FCX levels of DA and NA elicited by GR205171 together with 8-OH-DPAT or S15535, $5-\mathrm{HT}_{1 \mathrm{~A}}$ receptor agonists possessing antidepressant and anxiolytic properties (Lucki et al, 1994; Millan et al, 1997a, b; Millan, 2006). Third, $\mathrm{NK}_{2}$ and $\mathrm{NK}_{3}$ receptors influence mood and modulate monoaminergic pathways, possibly in interaction with $\mathrm{NK}_{1}$ receptors (Steinberg et al, 2001; Bert et al, 2002; Léger et al, 2002; Spooren et al, 2005). Accordingly, it would be interesting to examine how blockade of $\mathrm{NK}_{2}$ and $\mathrm{NK}_{3}$ receptors affects the functional actions of antidepressants.

\section{CONCLUSIONS}

The present observations strongly suggest that combining $\mathrm{NK}_{1}$ receptor blockade with suppression of 5-HT reuptake may yield benefits in the treatment of anxious and depressed states relative to selective $\mathrm{NK}_{1}$ antagonists and SSRIs.

\section{ACKNOWLEDGEMENTS}

We thank Marianne Soubeyran for secretarial assistance and Rodolphe Billiras, Raphael Boulanger, Laetitia Cistarelli, Loretta Iob, Dorothée Sicard, and Sylvie Veiga for technical assistance.

\section{DISCLOSURE/CONFLICT OF INTEREST}

Alain Gobert, Mauricette Brocco, Anne Dekeyne, Benjamin Di Cara, Gaëlle Bouchez, Françoise Lejeune, and Mark J Millan declare that, except for income received from their primary employer, no financial support or compensation has been received from any individual or corporate entity over the past 3 years for research or professional service and there are no personal financial holdings that could be perceived as constituting a potential conflict of interest. Robert L Gannon work's was funded in part by NSF IBN 0549980. Robert L. Gannon has received compensation from Servier and Shaw Science Partners.

\section{REFERENCES}

Adell A, Artigas F (2004). The somatodendritic release of dopamine in the ventral tegmental area and its regulation by afferent transmitter systems. Neurosci Biobehav Rev 28: 415-431.

Alex KD, Pehek EA (2007). Pharmacologic mechanisms of serotonergic regulation of dopamine neurotransmission. Pharmacol Ther 113: 296-320.

Artigas F, Celada P, Laruelle M, Adell A (2001). How does pindolol improve antidepressant action? TIPS 22: 224-228.

Bassi GS, Nobre MJ, Carvalho MC, Brandão ML (2007). Substance $\mathrm{P}$ injected into the dorsal periaqueductal gray causes anxiogenic effects similar to the long-term isolation as assessed by ultrasound vocalizations measurements. Behav Brain Res 182: 301-307.

Bert L, Rodier D, Bougault I, Allouard N, Le-Fur G, Soubrié P et al (2002). Permissive role of neurokinin $\mathrm{NK}_{3}$ receptors in $\mathrm{NK}_{1}$ receptor-mediated activation of the locus coeruleus revealed by SR 142801. Synapse 43: 62-69.

Blier P, Gobbi G, Haddjeri N, Santarelli L, Mathew G, Hen R (2004). Impact of substance $\mathrm{P}$ receptor antagonism on the serotonin and norepinephrine systems: relevance to the antidepressant/anxiolytic response. J Psychiatry Neurosci 29: 208-218.

Brocco M, Dekeyne A, Mannoury la Cour C, Touzard M, Girardon S, Veiga S et al (2008). Cellular and behavioural profile of the novel, selective neurokinin ${ }_{1}$ receptor antagonist, vestipitant: a comparison to other agents. Eur Neuropsychopharmacol 18: 729-750.

Brocco M, Dekeyne A, Papp M, Millan MJ (2006). Antidepressantlike properties of the anti-Parkinson agent, piribedil, in rodents: mediation by dopamine $\mathrm{D}_{2}$ receptors. Behav Pharmacol 17: $559-572$

Brocco M, Dekeyne A, Veiga S, Girardon S, Millan MJ (2002). Induction of hyperlocomotion in mice exposed to a novel environment by inhibition of serotonin reuptake a pharmacological characterization of diverse classes of antidepressant agents. Pharmacol Biochem Behav 71: 667-680.

Burghardt NS, Bush DEA, McEwen BS, LeDoux JE (2007). Acute selective serotonin reuptake inhibitors increase conditioned fear expression: blockade with a $5-\mathrm{HT}_{2 \mathrm{C}}$ receptor antagonist. Biol Psychiatry 62: 1111-1118.

Campbell BM, Merchant KM (2003). Serotonin ${ }_{2 C}$ receptors within the basolateral amygdala induce acute fear-like responses in an open-field environment. Brain Res 993: 1-9.

Celada P, Puig MV, Casanovas JM, Guillazo G, Artigas F (2001). Control of dorsal raphe serotonergic neurons by the medial prefrontal cortex: involvement of serotonin-1A, GABA(A), and glutamate receptors. J Neurosci 21: 9917-9929.

Chenu F, Guiard BP, Bourin M, Gardier AM (2006). Antidepressant-like activity of selective serotonin reuptake inhibitors combined with a $\mathrm{NK}_{1}$ receptor antagonist in the mouse forced swimming test. Behav Brain Res 172: 256-263.

Commons KG, Valentino RJ (2002). Cellular basis for the effects of substance $\mathrm{P}$ in the periaqueductal gray and dorsal raphe nucleus. J Comp Neurol 447: 82-97.

Conley RK, Cumberbatch MJ, Mason GS, Williamson DJ, Harrison $\mathrm{T}$, Locker $\mathrm{K}$ et al (2002). Substance $\mathrm{P}$ (neurokinin 1) receptor antagonists enhance dorsal raphe neuronal activity. J Neurosci 22: $7730-7736$. 
Cremers TI, Rea K, Bosker FJ, Wikström HV, Hogg S, Mork A et al (2007). Augmentation of SSRI effects on serotonin by $5-\mathrm{HT}_{2 \mathrm{C}}$ antagonists: mechanistic studies. Neuropsychopharmacology 31: 1550-1557.

Czeh B, Fuchs E, Simon M (2006). $\mathrm{NK}_{1}$ receptor antagonists under investigation for the treatment of affective disorders. Expert Opin Investig Drugs 15: 479-486.

Dableh LJ, Yashpal K, Rochford J, Henry JL (2005). Antidepressant-like effects of neurokinin receptor antagonists in the forced swim test in the rat. Eur J Pharmacol 507: 99-105.

De Vry J, Benz U, Schreiber R, Traber J (1993). Shock-induced ultrasonic vocalization in young adult rats: a model for testing putative anti-anxiety drugs. Eur J Pharmacol 249: 331-339.

Dekeyne A, Denorme B, Monneyron S, Millan MJ (2000). Citalopram reduces social interaction in rats by activation of serotonin (5-HT) ${ }_{2 \mathrm{C}}$ receptors. Neuropharmacology 39: 114-1117.

Duncan WC (1996). Circadian rhythms and the pharmacology of affective illness. Pharmacol Ther 71: 253-312.

Ebner K, Rupniak NM, Saria A, Singewald N (2004). Substance P in the medial amygdala: emotional stress-sensitive release and modulation of anxiety-related behavior in rats. Proc Natl Acad Sci USA 101: 4280-4285.

Ebner K, Singewald GM (2007). Stress-induced release of substance $\mathrm{P}$ in the locus coeruleus modulates cortical noradrenaline release. Naunyn Schmiedebergs Arch Pharmacol 376: 73-82.

Ebner K, Singewald GM, Whittle N, Ferraguti F, Singewald N

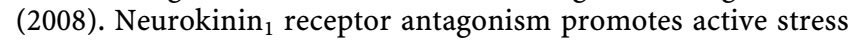
coping via enhanced septal $5-\mathrm{HT}_{1 \mathrm{~A}}$ transmission. Neuropsychopharmacology 33: 1929-1941.

Engberg S, Ahlstedt I, Leffler A, Lindström E, Kristensson E, Svensson A et al (2007). Molecular cloning, mutations and effects of $\mathrm{NK}_{1}$ receptor antagonists reveal the human-like pharmacology of gerbil $\mathrm{NK}_{1}$ receptors. Biochem Pharmacol 73: 259-269.

File SE (1997). Anxiolytic action of a neurokinin 1 receptor antagonist in the social interaction test. Pharmacol Biochem Behav 58: 747-752.

Froger N, Gardier AM, Moratalla R, Alberti I, Lena I, Boni C et al (2001). 5-hydroxytryptamine $(5-\mathrm{HT})_{1 \mathrm{~A}}$ autoreceptor adaptive changes in substance $\mathrm{P}$ (neurokinin ${ }_{1}$ ) receptor knock-out mice mimic antidepressant-induced desensitization. Neuroscience 15: 8188-8197.

Furmark T, Appel L, Michelgård A, Wahlstedt K, Ahs F, Zancan S et al (2005). Cerebral flow changes after treatment of social phobia with the neurokinin-1 antagonist GR205171, citalopram or placebo. Biol Psychiatry 58: 132-142.

Gannon RI, Millan MJ (2005). The selective neurokinin ${ }_{1}\left(\mathrm{NK}_{1}\right)$ receptor antagonist, GR 205171, stereospecifically inhibits lightinduced phase shifts of hamster circadian activity rhythms. Eur J Pharmacol 527: 86-93.

Gannon RL, Millan MJ (2007). Evaluation of serotonin, noradrenaline and dopamine reuptake inhibitors on light-induced phase advances in hamster circadian activity rhythms. Psychopharmacology 195: 325-332.

Gardner CJ, Armour DR, Beattie DT, Gale JD, Hawcock AB, Kilpatrick GJ et al (1996). GR205171: a novel antagonist with high affinity for the tachykinin $\mathrm{NK}_{1}$ receptor, and potent broadspectrum anti-emetic activity. Regul Pept 65: 45-53.

Garret C, Carruette A, Fardin V, Moussoui S, Peyronel JF, Blanchard JC et al (1991). Pharmacological properties of a potent and selective nonpeptide substance P antagonist. Proc Natl Acad Sci USA 88: 10208-10212.

Gerald CPG, Antonijevic IA, Branchek TA (2006). Novel mechanisms to treat depression and anxiety. Will neuropeptide antagonists succeed? Drug Discov Today Ther Strateg 4: 467-473.

Gobbi G, Cassano T, Radja F, Morgese MG, Cuomo V, Santarelli L et al (2007). Neurokinin 1 receptor antagonism requires norepinephrine to increase serotonin function. Eur Neuropsychopharmacol 17: 328-338.
Gobert A, Lejeune F, Rivet J-M, Audinot V, Newman-Tancredi A, Millan MJ (1995). Modulation of the activity of central serotoninergic neurones by novel serotonin ${ }_{1 \mathrm{~A}}$ receptor agonists and antagonists: A comparison to adrenergic and dopaminergic neurones in individual rats. J Pharmacol Exp Ther 273: 1032-1046.

Gobert A, Rivet JM, Cistarelli L, Melon C, Millan MJ (1999). Buspirone modulates basal and fluoxetine-stimulated dialysate levels of dopamine, noradrenaline and serotonin in the frontal cortex of freely moving rats: activation of serotonin $n_{1 \mathrm{~A}}$ receptors and blockade of alpha $\mathrm{a}_{2}$-adrenergic receptors underlie its actions. Neuroscience 93: 1251-1262.

Gobert A, Rivet J-M, Cistarelli L, Millan MJ (1997). Potentiation of the fluoxetine-induced increase in dialysate levels of serotonin (5-HT) in the frontal cortex of freely-moving rats by combined blockade of 5- $\mathrm{HT}_{1 \mathrm{~A}}$ and $5-\mathrm{HT}_{1 \mathrm{~B}}$ receptors with WAY100 635 and GR127 935. J Neurochem 68: 1159-1163.

Griffante C, Carletti R, Andreetta F, Corsi M (2006). [ $\left.{ }^{3} \mathrm{H}\right]$ GR205171 displays similar $\mathrm{NK}_{1}$ receptor binding profile in gerbil and human brain. Br J Pharmacol 148: 39-45.

Guiard BP, Froger N, Hamon M, Gardier AM, Lanfumey L (2005). Sustained pharmacological blockage of $\mathrm{NK}_{1}$ substance $\mathrm{P}$ receptors causes functional desensitization of dorsal raphe 5$\mathrm{HT}_{1 \mathrm{~A}}$ autoreceptors in mice. J Neurochem 95: 1713-1723.

Guiard BP, Guilloux JP, Reperant C, Hunt SP, Toth M, Gardier AM (2007). Substance P neurokinin ${ }_{1}$ receptor activation within the dorsal raphe nucleus controls serotonin release in the mouse frontal cortex. Mol Pharmacol 72: 1411-1418.

Guiard BP, Przybylski C, Guilloux JP, Seif I, Froger N, de Felipe C et al (2004). Blockade of substance $\mathrm{P}$ (neurokinin ${ }_{1}$ ) receptors enhances extracellular serotonin when combined with a selective serotonin reuptake inhibitor: an in vivo microdialysis study in mice. J Neurochem 89: 54-63.

Guilloux JP, David DJ, Guiard BP, Chenu F, Repérant C, Toth M et al (2006). Blockade of $5-\mathrm{HT}_{1 \mathrm{~A}}$ receptors by $(+/-)$-pindolol potentiates cortical 5-HT outflow, but not antidepressant-like activity of paroxetine: microdialysis and behavioural approaches in $5-\mathrm{HT}_{1 \mathrm{~A}}$ receptor knockout mice. Neuropsychopharmacology 31: $2162-2172$.

Haddjeri N, Blier P (2000). Effect of neurokinin- ${ }_{1}$ receptor antagonists on the function of 5-HT and noradrenaline neurons. Neuroreport 11: 1323-1327.

Haddjeri N, Blier P (2001). Sustained blockade of neurokinin-1 receptors enhances serotonin neurotransmission. Biol Psychiatry 50: 191-199.

Haddjeri N, Lucas G, Blier P (2000). Role of cholinergic and GABAergic systems in the feedback inhibition of dorsal raphe 5-HT neurons. Neuroreport 11: 3397-3401.

Herpfer L, Hunt SP, Stanford SC (2005). A comparison of neurokinin $_{1}$ receptor knock-out $\left(\mathrm{NK}_{1}-/-\right)$ and wildtype mice: exploratory behaviour and extracellular noradrenaline concentration in the cerebral cortex of anaesthetised subjects. Neuropharmacology 48: 706-719.

Holmes A, Heilig M, Rupniak NMJ, Steckler T, Griebel G (2003). Neuropeptide systems as novel therapeutic targets for depression and anxiety disorders. Trends Pharmacol Sci 24: 580-588.

Invernizzi RW, Pierucci M, Calcagno E, Di Giovanni G, Di Matteo $\mathrm{V}$, Benigno A et al (2007). Selective activation of $5-\mathrm{HT}_{2 \mathrm{C}}$ receptors stimulates $\mathrm{GABA}$-ergic function in the rat substantia nigra pars reticulata: a combined in vivo electrophysiological and neurochemical study. Neuroscience 144: 1523-1535.

Kramer MS, Cutler NR, Keighner J, Shrivastava R, Carman J, Sramek JJ et al (1998). Distinct mechanism for antidepressant activity by blockade of central substance P receptors. Science 281: $1640-1645$.

Kramer MS, Winokur A, Kelsey J, Preskorn SH, Rothschild AJ, Snavely D et al (2004). Demonstration of the efficacy and safety of a novel substance $\mathrm{P}\left(\mathrm{NK}_{1}\right)$ receptor antagonist in major depression. Neuropsychopharmacology 29: 385-392. 
Lacoste B, Riad M, Descarries L (2006). Immunocytochemical evidence for the existence of substance $\mathrm{P}$ receptor $\left(\mathrm{NK}_{1}\right)$ in serotonin neurons of rat and mouse dorsal raphe nucleus. Eur $J$ Neurosci 23: 2947-2958.

Léger L, Gay N, Cespuglio R (2002). Neurokinin $\mathrm{NK}_{1-}$ and $\mathrm{NK}_{3}$ immunoreactive neurons in serotonergic cell groups in the rat brain. Neurosci Lett 323: 146-150.

Legutko R, Gannon RL (2001). Serotonin transporter localization in the hamster suprachiasmatic nucleus. Brain Res 893: 77-83.

Lejeune F, Gobert A, Millan MJ (2002). The selective neurokinin (NK) 1 antagonist, GR205171, stereospecifically enhances mesocortical dopaminergic transmission in the rat: a combined dialysis and electrophysiological study. Brain Res 935: 134-139.

Lejeune F, Millan MJ (2000). Pindolol excites dopaminergic and adrenergic neurons, and inhibits serotonergic neurons, by activation of 5- $\mathrm{HT}_{1 \mathrm{~A}}$ receptors. Eur J Neurosci 12: 3265-3275.

Lejeune F, Newman-Tancredi A, Audinot V, Millan MJ (1997). Interaction of (+)- and (-)-8- and 7-hydroxy-2-(di-n-propylamino)tetraline at human $(\mathrm{h}) \mathrm{D}_{3}, \mathrm{hD}_{2}$ and $\mathrm{h}$ serotonin $\mathrm{n}_{1 \mathrm{~A}}$ receptors and their modulation of the activity of serotonergic and dopaminergic neurones in rats. J Pharmacol Exp Ther 280: 1241-1249.

Lessard A, Pickel VM (2005). Subcellular distribution and plasticity of neurokinin-1 receptors in the rat substantia nigra and ventral tegmental area. Neuroscience 135: 1309-1323.

Lieb K, Fiebich BL, Herpfer I, Mantovani M, Löffler M, Feuerstein TJ (2005). No modulatory effect of neurokinin-1 ${ }_{1}$ receptor antagonists on serotonin uptake in human and rat brain synaptosomes. Eur Neuropsychopharmacol 15: 641-646.

Liu R, Ding Y, Aghajanian GK (2002). Neurokinins activate local glutamatergic inputs to serotonergic neurons of the dorsal raphe nucleus. Neuropsychopharmacology 27: 329-340.

Lucki I, Singh A, Kreiss DS (1994). Antidepressant-like behavioral effects of serotonin receptor agonists. Neurosci Biobehav Rev 18: 85-95.

Ma Q-P, Bleasdale C (2002). Modulation of brain stem monoamines and gamma aminobutyric acid by $\mathrm{NK}_{1}$ receptors in rats. Neuroreport 13: 1809-1813.

Maubach KA, Martin K, Chicchi G, Harrison T, Wheeldon A, Swain CJ et al (2002). Chronic substance $\mathrm{P}\left(\mathrm{NK}_{1}\right)$ receptor antagonist and conventional antidepressant treatment increases burst firing of monoamine neurones in the locus coeruleus. Neuroscience 109: 609-617.

Michelgard A, Appel L, Pissiota A, Frans O, Langström B, Bergström $M$ et al (2007). Symptom provocation in specific phobia affects the substance $\mathrm{P}$ neurokinin-1 receptor system. Biol Psychiatry 61: 1002-1006.

Millan MJ (2003). The neurobiology and control anxious states. Prog Neurobiol 70: 83-244.

Millan MJ (2004). The role of monoamines in the action of established and 'novel' antidepressant agents: a critical review. Eur J Pharmacol 500: 371-384.

Millan MJ (2006). Multi-target strategies for the improved treatment of depressive states: conceptual foundations and neuronal substrates, drug discovery and therapeutic application. Pharmacol Ther 110: 135-370.

Millan MJ, Brocco M, Gobert A, Dorey G, Casara P, Dekeyne A (2001a). Anxiolytic properties of the selective, non-peptidergic $\mathrm{CRF}_{1}$ antagonists, CP154526 and DMP695: a comparison to other classes of anxiolytic agent. Neuropsychopharmacology 25: 585-600.

Millan MJ, Gobert A (1999). (-)-Pindolol increases dialysate concentrations of dopamine and noradrenaline, but not serotonin, in the frontal cortex of freely-moving rats. Neuropharmacology 38: 909-912.

Millan MJ, Hjorth S, Samanin R, Schreiber R, Jaffard R, De Ladonchamps B et al (1997a). S15535, a novel benzodioxopiperazine ligand of serotonin $(5-\mathrm{HT})_{1 \mathrm{~A}}$ receptors: II. Modulation of hippocampal serotonin release in relation to potential anxiolytic properties. J Pharmacol Exp Ther 282: 148-161.

Millan MJ, Lejeune F, De Nanteuil G, Gobert A (2001b). Selective blockade of neurokinin $(\mathrm{NK})_{1}$ receptors facilitates the activity of adrenergic pathways projecting to the frontal cortex and dorsal hippocampus in the rat. J Neurochem 76: 1949-1954.

Millan MJ, Lejeune F, Gobert A (2000). Reciprocal autoreceptor and heteroceptor control of serotonergic, dopaminergic and adrenergic transmission in frontal cortex: a review, and relevance to the actions of antidepressant agents. J Psychopharmacol 14: 114-138.

Millan MJ, Newman-Tancredi A, Rivet JM, Brocco M, Lacroix P, Audinot V et al (1997b). S15535, a novel benzodioxopiperazine ligand of serotonin (5-HT)1A receptors: I. Interaction with cloned human (h)5- $\mathrm{HT}_{1 \mathrm{~A}}$, dopamine $\mathrm{hD} 2 / \mathrm{hD} 3$ and ha2Aadrenergic receptors in relation to modulation of cortical monoamine release and activity in models of potential antidepressant activity. J Pharmacol Exp Ther 282: 132-147.

Molewijk HE, Hartog K, van der Poel AM, Mos J, Olivier B (1996). Reduction of guinea pig pup isolation calls by anxiolytic and antidepressant drugs. Psychopharmacology 128: 31-38.

Morilak DA, Frazer A (2004). Antidepressants and brain monoaminergic systems: a dimensional approach to understanding their behavioural effects in depression and anxiety disorders. Int J Neuropsychopharmacol 7: 193-218.

Newman-Tancredi A, Chaput C, Gavaudan S, Verrièle L, Millan MJ (1998). Agonist and antagonist action of (-)-pindolol at recombinant, human 5- $\mathrm{HT}_{1 \mathrm{~A}}$ receptors. Neuropsychopharmacology 18: 395-398.

Redrobe JP, Bourin M (1998). Dose-dependent influence of buspirone on the activities of selective serotonin reuptake inhibitors in the mouse forced swimming test. Psychopharmacology 138: 198-206.

Renoldi G, Invernizzi RW (2006). Blockade of tachikinin $\mathrm{NK}_{1}$ receptors attenuates stress-induced rise of extracellular noradrenaline and dopamine in the rat and gerbil medial prefrontal. J Neurosci Res 84: 961-968.

Rupniak NM, Carlson EC, Harrison T, Oates B, Seward E, Owen S et al (2000). Pharmacological blockade or genetic deletion of substance $\mathrm{P}\left(\mathrm{NK}_{1}\right)$ receptors attenuates neonatal vocalisation in guinea-pigs and mice. Neuropharmacology 39: 1413-1421.

Rupniak NM, Carlson EJ, Webb JK, Harrison T, Porsolt RD, Roux $S$ et al (2001). Comparison of the phenotype of $\mathrm{NK}_{1} \mathrm{R}-/-$ mice with pharmacological blockade of the substance $\mathrm{P}\left(\mathrm{NK}_{1}\right)$ receptor in assays for antidepressant and anxiolytic drugs. Behav Pharmacol 12: 497-508.

Rupniak NMJ, Webb JK, Fisher A, Smith D, Boyce S (2003). The substance $\mathrm{P}\left(\mathrm{NK}_{1}\right)$ receptor antagonist L-760735 inhibits fear conditioning in gerbils. Neuropharmacology 44: 516-523.

Ryckmans T, Berton O, Grimée R, Kogej T, Lamberty Y, Pasau P et al (2002). Dual $\mathrm{NK}_{1}$ antagonists-serotonin reuptake inhibitors as potential antidepressants. Part 2: SAR and activity of benzyloxyphenethyl piperazine derivatives. Bioorg Med Chem Lett 12: 3195-3198.

Saffroy M, Torrens Y, Glowinski J, Beaujouan J-C (2003). Autoradiographic distribution of tachykinin $\mathrm{NK}_{2}$ binding sites in the rat brain: comparison with $\mathrm{NK}_{1}$ and $\mathrm{NK}_{3}$ binding sites. Neuroscience 116: 761-773.

Salchner P, Singewald N (2006). 5-HT receptor subtypes involved in the anxiogenic-like action and associated Fos response of acute fluoxetine treatment in rats. Psychopharmacology 185: 282-288.

Sánchez C (2003). Stress-induced vocalization in adult animals. A valid model of anxiety? Eur J Pharmacol 463: 133-143.

Sanchez C, Meier E (1997). Behavioral profiles of SSRIs in animal models of depression, anxiety and aggression. Are they all alike? Psychopharmaocology 129: 197-205. 
Santarelli L, Gobbi G, Debs PC, Sibille EL, Blier P, Hen R et al (2001). Genetic and pharmacological distribution of neurokinin 1 receptor function decreases anxiety-related behaviors and increases serotonergic function. Proc Natl Acad Sci USA 98: 1912-1917.

Sartori SB, Burnet PWJ, Sharp T, Singewald N (2004). Evaluation of the effect of chronic antidepressant treatment on neurokinin-1 receptor expression in the rat brain. Neuropharmacology 46: 1177-1183.

Sharp T, Boothman L, Raley J, Quérée P (2007). Important messages in the 'post': recent discoveries in 5-HT neurone feedback control. TiNS 28: 629-636.

Sheehan TP, Chambers RA, Russell DS (2004). Regulation of affect by the lateral septum: implications for neuropsychiatry. Brain Res Rev 46: 71-117.

Shirayama Y, Mitsushio H, Takashima M, Ichikawa H, Takahashi K (1996). Reduction of substance P after chronic antidepressants treatment in the striatum, substantia nigra and amygdala of the rat. Brain Res 739: 70-78.

Sloviter RS, Ali-Akbarian L, Horvath KD, Menkens KA (2001). Substance $\mathrm{P}$ receptor expression by inhibitory interneurons of the rat hippocampus: enhanced detection using improved immunocytochemical methods for the preservation and coloca- lization of GABA and other neuronal markers. J Comp Neurol 430: 283-305.

Spooren W, Riemer C, Meltzer $\mathrm{H}$ (2005). $\mathrm{NK}_{3}$ receptor antagonists: the next generation of antipsychotics? Nat Rev Drug Discov 4: 967-975.

Stacey AE, Woodhall GL, Jones RSG (2002). Activation of neurokinin $_{1}$ receptors GABA release at synapses in rat entorhinal cortex. Neuroscience 115: 575-586.

Steinberg R, Alonso R, Griebel G, Bert L, Jung M, Oury-Donat F et al (2001). Selective blockade of neurokinin-2 receptors produces antidepressant-like effects associated with reduced corticotrophin-releasing factor function. J Pharmacol Exp Ther 299: 449-458.

Szeidemann Z, Jakab RL, Shanabrough M, Leranth C (1995). Extrinsic and intrinsic substance $\mathrm{P}$ innervation of the rat lateral septal area calbindin cells. Neuroscience 69: 1205-1221.

Valentino RJ, Bey V, Pernar L, Commons KG (2003). Substance P acts through local circuits within the rat dorsal raphe nucleus to alter serotonergic neuronal activity. J Neurosci 23: 7155-7159.

Varty GB, Cohen-Williams ME, Morgan CA, Pylak U, Duffy RA, Lachowicz JE et al (2002). The gerbil elevated plus-maze II: anxiolytic-like effects of selective neurokinin $\mathrm{NK}_{1}$ receptor antagonists. Neuropsychopharmacology 27: 371-379. 